\title{
Is the Poverty of the Country a Consequence of the Structure of the Mexican Economy?
}

\author{
Dora Elena Ledesma-Carrión* and Lidia Hernández-Hernández
}

Instituto Nacional de Estadística y Geografía (INEGI), Av. Patriotismo 711, Col. San Juan Mixcoac, C.P. 03730, Benito Juárez, México

\begin{abstract}
As has been observed for decades, poverty alleviation programs have not ended this generational social debt Isolated policies such as the per capita wage increase sound attractive but do not greatly benefit households with incomes below the minimum welfare line. Also, the most powerful industry in this country is the manufacture of petroleum and coal products, it does not help solve the increase in the number of people living in poverty. It is the wholesale trade in groceries and food that impacts both on the change in the poverty index and on its depth and intensity. This explains how households with incomes between the first and fifth decile of income remain within the informal trade.
\end{abstract}

Keywords: Social accounting matrix; Decomposition of multipliers; Poverty index

\section{Introduction}

The concepts and opinions expressed in this document represent only the point of view of the authors; Do not necessarily reflect the vision of the institution to which they belong. Much has been said about poverty in Mexico and its causes, but for many years we have been in recurrent crises that do not allow for its decline [1-3]. The objective of this paper is to present the multiplier decomposition method [4,5] applied to a social accounting matrix (SAM-MX120 [6,7] built for 2012 and to focus it on the analysis of poverty alleviation using the FosterGreer-Thorbecke index [8]. The SAM-MX12 is based on the Mexican System of National Accounts (SCNM-MX) and includes the inputoutput matrix (IOT-MX12) as intermediate consumption $[6,9]$ and the tariff databases were coupled with the North America Industrial Classification System, NAICS 2007 code [10-12].

More information on the construction of SAM can be found in the previous papers $[13,14]$.

In the Official Journal of the Federation dated 16 of 2010, the general guidelines and criteria for the definition, identification and measurement of poverty are established. National Council for Evaluation of Social Development Policy (CONEVAL) defines that a person is in multidimensional poverty when he is not guaranteed the exercise of at least one of his rights for social development, and if his income is insufficient to acquire the goods and services that he needs to satisfy his needs. Regarding economic well-being, only per capita current income is taken into account. While social rights are used for social rights related to education, health, social security, food, housing and services [15]. Here the economic welfare line will be taken and as the upper limit the welfare line denoted as $\check{z}$, and if it is the minimum welfare line will be $\mathrm{z}$.

\section{Brief State of the Art}

Thorbecke and Jung [8] apply the poverty indicator proposed by Foster-Greer-Thorbecke to Indonesia's economy with 76 economic sectors including 23 categories for rural and urban areas. Households are subdivided into eight groups depending on their average income and companies linked to 24 productive activities. Kim [16] does the same for South Africa by distinguishing between sex and skilled and unskilled workers. It uses the same social accounting matrix structure proposed by Defourny and Thorbecke in 1984 [5]. For both analyzes, it was necessary to have additional information on elasticities for rural and urban areas of poverty for different groups of employees in different sectors.

During the 50s, Antonio Ortiz Mena [1] argued that resolving the situation of the lower income population, especially in rural areas, was crucial for the true stabilizing development of the Nation. Many decades of this have passed and this inequality still persists and the gap between the poor and the rich has widened. Taking the historical data and definitions of poverty in the different periods, the following graphs, Figures 1a-1c which show what has been said [2].

Alcides Lasa and Deuda [3] points out that over time the national real wage index or simply the real wage shows the increase in poverty. Resuming what indicated in ref. [2] calculates the current equivalent salary with Instituto Nacional de Estadística y Geografía (National Institute of Statistic and Geography, INEGI) data of the minimum wage of 1935-2015, Figure 2 shows that the minimum wage in 1938 was higher than the current one and that controlled inflation is not determinant in the wage increase.

The false wage increase during Luis Echeverría's tenure with uncontrolled inflation led to a brutal decline in purchasing power over the next four years. But before Echeverría, the wage increase by presidential decree had worked during the mandates of Adolfo López Mateos and Gustavo Díaz Ordaz with controlled inflation, 2b. That is, if inflation is not controlled, the wage increase is risky because it depends on many other factors such as the production of crude oil and its derivatives, the domestic market, the interest rate, the trade balance and the peso-dollar exchange rate. All this impacts on what Mexicans are

*Corresponding author: Dora Elena Ledesma-Carrión, Instituto Naciona de Estadística y Geografía (INEGI), Av. Patriotismo 711, Col. San Juan Mixcoac, C.P. 03730, Benito Juárez, México, Tel: 52781000; Ext. 1624; E-mail: dora.ledesma@inegi.org.mx

Received January 26, 2017; Accepted June 27, 2017; Published June 30, 2017

Citation: Ledesma-Carrión DE, Hernández-Hernández L (2017) Is the Poverty of the Country a Consequence of the Structure of the Mexican Economy? Int J Account Res 5: 163. doi:10.4172/2472-114X.1000163

Copyright: (c 2017 Ledesma-Carrión DE, et al. This is an open-access article distributed under the terms of the Creative Commons Attribution License, which permits unrestricted use, distribution, and reproduction in any medium, provided the original author and source are credited. 
Citation: Ledesma-Carrión DE, Hernández-Hernández L (2017) Is the Poverty of the Country a Consequence of the Structure of the Mexican Economy? Int J Account Res 5: 163. doi:10.4172/2472-114X.1000163
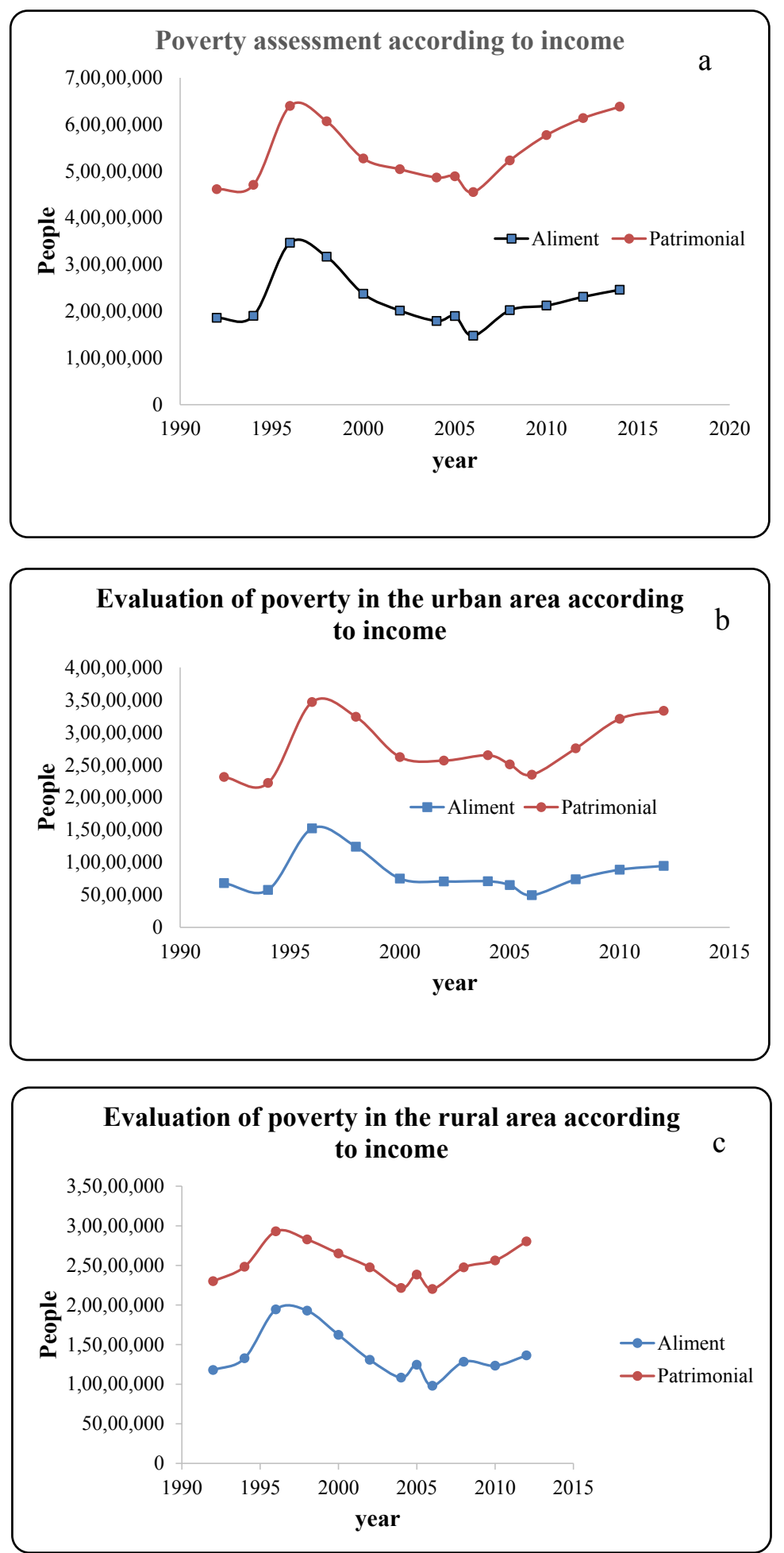

Figure 1: Line of food poverty (line of minimum welfare) and patrimonial (economic welfare line from 2014) from 1992 to 2012. a) Population, b) in urban areas and $\mathrm{c}$ ) in rural areas.

looking for, a well-paid and long-term job. It is required that employment through SMEs is generated, for it requires entrepreneurs and trained people. This leads us to the other poverty or social deficiencies that are not taken into account in the present work for 2012, the percentages of the population with educational lag by decile are: I (34.3), II (29.5), III (25.3), IV (22.1), V (20.1), VI (17.9), VII (16.0), VIII (13.2), IX (9.4) and $\mathrm{X}$ (4.6). These percentages are high, so the problem of poverty must study these other aspects, which is open to further research. 

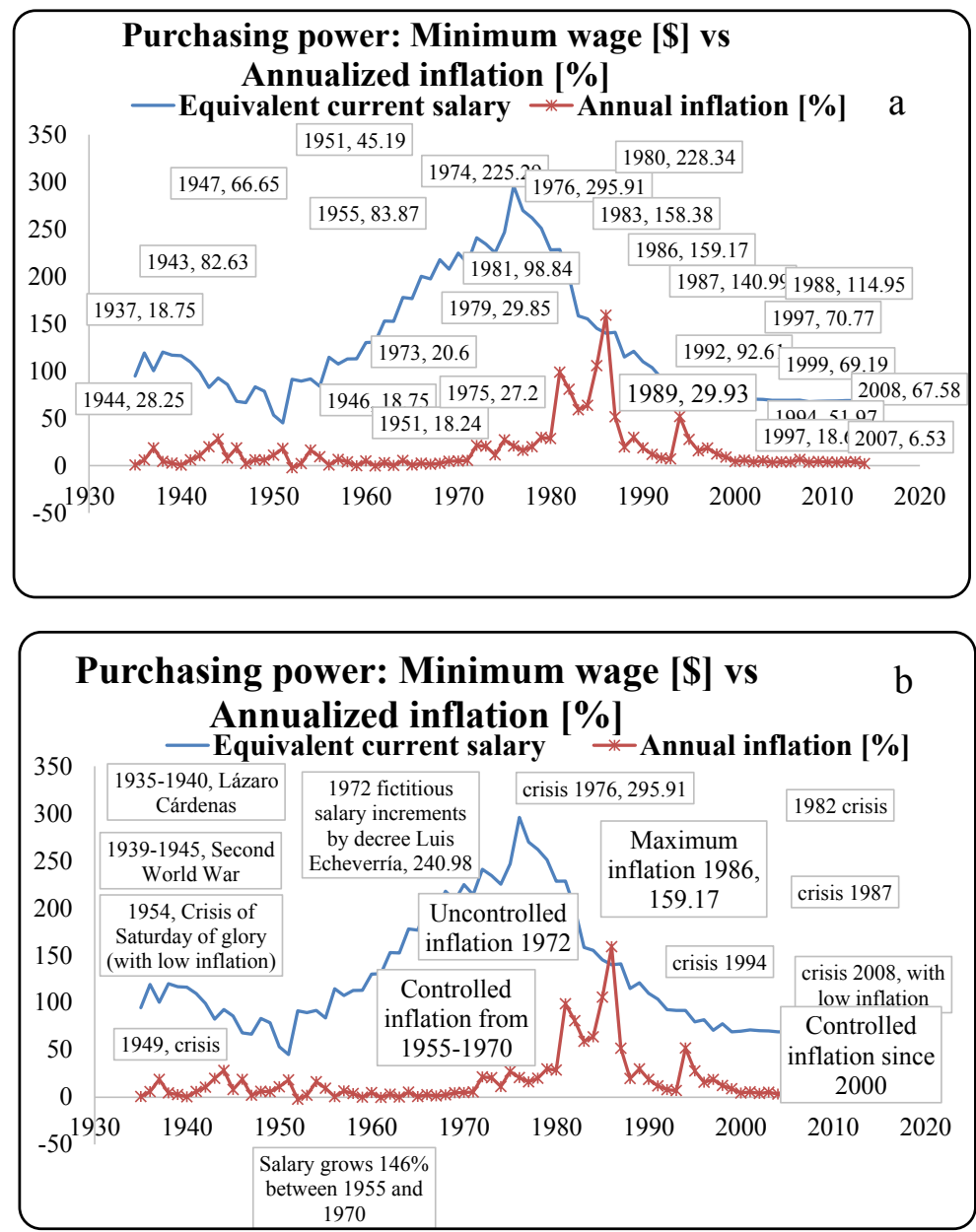

Figure 2: Historical mínimum wage and annual inflation 1934-2012: a) Inflation and minimum wage data and, b) Historical facts.

\section{Methodology}

The economic conceptual framework is described in Figure 3a and, starting from a social accounting matrix (SAM-MX12) where the money flows from the columns and arrive at rows is constructed in the form of Defourny and Thorbecke $[4,17,18]$ (Figure 3b). Figure $3 \mathrm{c}$ schematizes the multiplier effect between endogenous accounts of SAM-MX12. When it comes to households, the distribution will be in terms of income or expenditure, according to the direction of flow. The distribution by deciles of both income and expenditure of the Survey of Household income and expenditure (ENIGH-12) that were adjusted to SCNM.

$\mathrm{X}_{1}$ is the final exogenous demand for government consumption factors, exports and investment demand:

$$
A_{13} X_{1}
$$

$\mathrm{X}_{2}$ is the exogenous injection from government transfers and remittances abroad:

$$
\left(\mathbb{I}-A_{22}\right)^{-1} X_{2}
$$

$\mathrm{X}_{3}$ is the final exogenous demand for government consumption, exports and investment demand:

$$
\left(\mathbb{I}-A_{33}\right)^{-1} X_{3}
$$

Subsequently, normalizing by columns and renaming sub-matrices as:

$$
\begin{aligned}
& y_{1}=A_{13} y_{3}+x_{1} \\
& y_{2}=A_{21} y_{1}+A_{22} y_{2}+x_{2} \\
& y_{3}=0+A_{22} y_{2}+A_{33} y_{3}+x_{3} \\
& \mathbb{A}_{n}=\left[\begin{array}{ccc}
0 & 0 & A_{13} \\
A_{21} & A_{22} & 0 \\
0 & A_{32} & A_{33}
\end{array}\right] \\
& Y_{n}=\mathbb{A}_{n} Y_{n}+X \\
& Y_{n}=\left(\mathbb{I}-\mathbb{A}_{n}\right)^{-1} X \\
& Y_{n}=\mathbb{M}_{n} X \\
& y_{1}=A_{13} y_{3}+x_{1}
\end{aligned}
$$

Solving the system

$$
\begin{aligned}
& y_{1}=A_{13} y_{3}+x_{1} \\
& y_{2}=\left(\mathbb{I}-A_{22}\right)^{-1} A_{21} y_{1}+\left(\mathbb{I}-A_{22}\right)^{-1} x_{2} \\
& y_{3}=\left(\mathbb{I}-A_{33}\right)^{-1} A_{32} y_{2}+\left(\mathbb{I}-A_{33}\right)^{-1} x_{3}
\end{aligned}
$$


Citation: Ledesma-Carrión DE, Hernández-Hernández L (2017) Is the Poverty of the Country a Consequence of the Structure of the Mexican Economy? Int J Account Res 5: 163. doi:10.4172/2472-114X.1000163

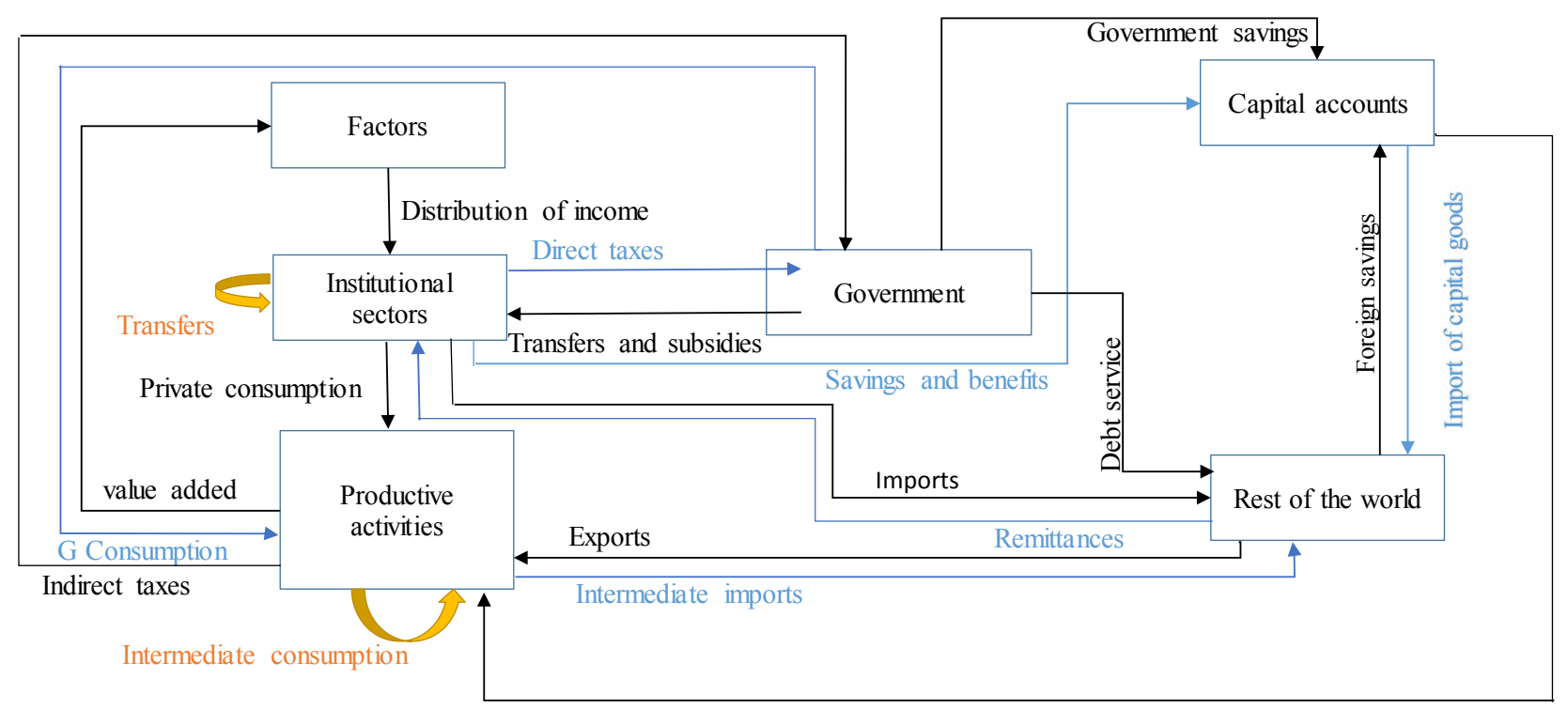

Investment

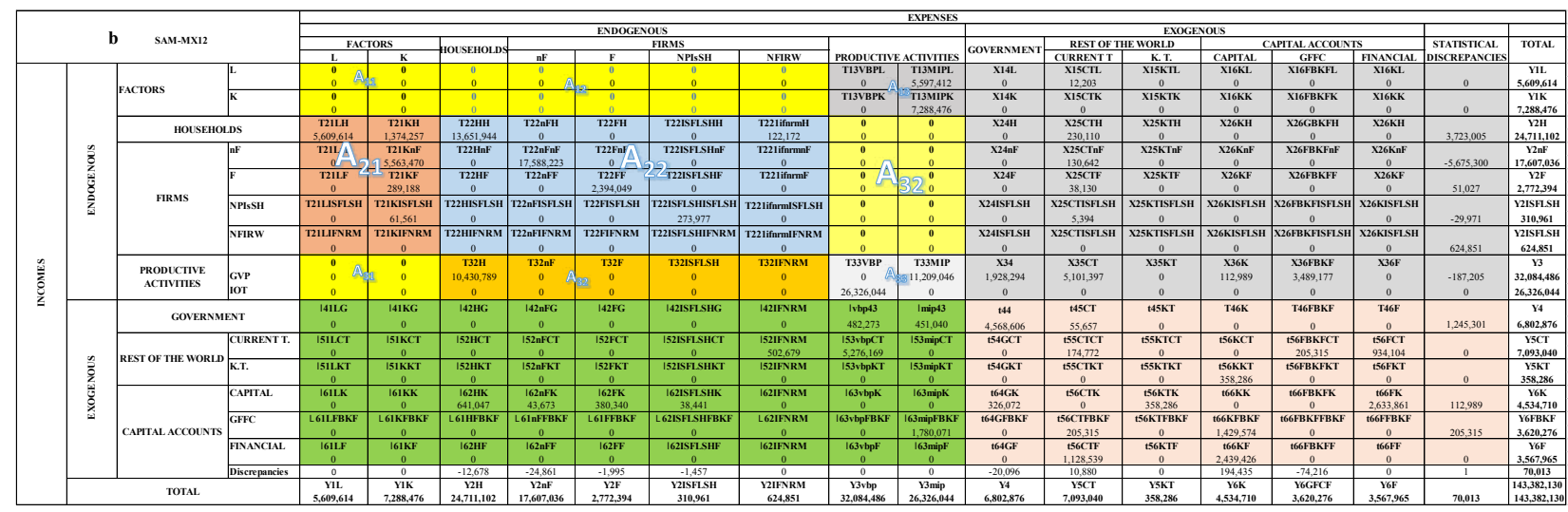

CURRENT T.- Current transferens; K.T. Capital transferences; GFFC.- Gross formation of fixed capital; F.- Financial firms; nF.- No-financial firms; NPIsSH.-Non-Profit institutions serving households; NFIRW.- Net factor income fromto the rest of the world.

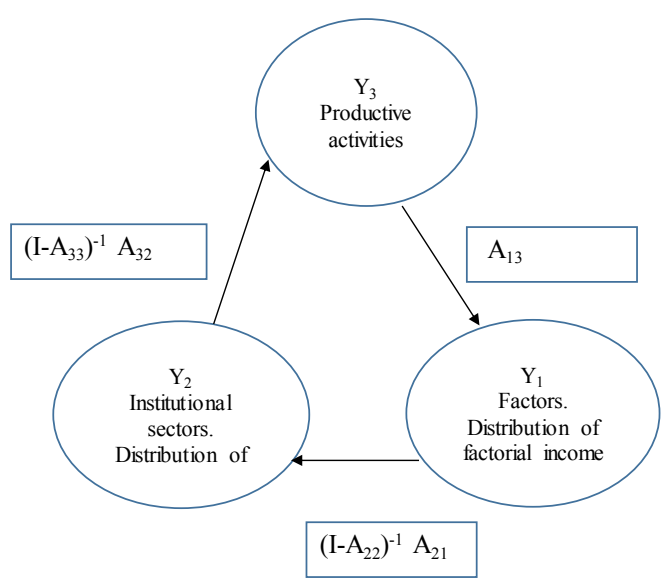

Figure 3: a) Flow chart of the SAM-MX12. b) Social accounting matrix with structure of Defourny \& Thorbecke, year 2012. c) Diagram of the multiplier process between endogenous accounts of SAM-MX12. 


$$
\begin{aligned}
& {\left[\begin{array}{l}
y_{1} \\
y_{2} \\
y_{3}
\end{array}\right]=\left[\begin{array}{ccc}
0 & 0 & A_{13} \\
\left(\mathbb{I}-A_{22}\right)^{-1} A_{21} & 0 & 0 \\
0 & \left(\mathbb{I}-A_{33}\right)^{-1} A_{32} & 0
\end{array}\right]\left[\begin{array}{l}
y_{1} \\
y_{2} \\
y_{3}
\end{array}\right]+\left[\begin{array}{ccc}
1 & 0 & 0 \\
0 & \left(\mathbb{I}-A_{22}\right)^{-1} & 0 \\
0 & 0 & \left(\mathbb{I}-A_{33}\right)^{-1}
\end{array}\right]\left[\begin{array}{l}
x_{1} \\
x_{2} \\
x_{3}
\end{array}\right]} \\
& \mathbb{A}_{I}=\left[\begin{array}{ccc}
0 & 0 & A_{13} \\
\left(\mathbb{I}-A_{22}\right)^{-1} A_{21} & 0 & 0 \\
0 & \left(\mathbb{I}-A_{33}\right)^{-1} A_{32} & 0
\end{array}\right] \\
& \mathbb{A}_{I I}=\left[\begin{array}{ccc}
1 & 0 & 0 \\
0 & \left(\mathbb{I}-A_{22}\right)^{-1} & 0 \\
0 & 0 & \left(\mathbb{I}-A_{33}\right)^{-1}
\end{array}\right] \\
& Y_{n}=\mathbb{A}_{I n} Y_{n}+\mathbb{A}_{I I n} X \\
& Y_{n}=\left(\mathbb{I}-\mathbb{A}_{I n}\right)^{-1} \mathbb{A}_{I n} X \\
& Y_{n}=\mathbb{M}_{n}^{*} X
\end{aligned}
$$

If one works with the marginal propensities to the expense or consumption and follows the same procedure it is gotten to substitute $\mathbb{A}_{\mathrm{n}} \rightarrow \mathbb{C}_{\mathrm{n}}$

$\mathbb{C}_{\mathrm{n}}=\left[\begin{array}{cc}\mathbb{A}_{\mathrm{n}} & \mathrm{X} \\ \mathrm{L} & \mathrm{t} \\ 1 & 1\end{array}\right]=\left[\begin{array}{ccc}\mathrm{c}_{11}=\frac{\mathrm{S}_{11}}{\mathrm{~S}_{11}} & \cdots & \mathrm{c}_{1 \mathrm{n}}=\frac{\mathrm{S}_{1 \mathrm{n}}}{\mathrm{S}_{1 \mathrm{n}}} \\ \vdots & \ddots & \vdots \\ \mathrm{c}_{\mathrm{n} 1}=\frac{\mathrm{S}_{\mathrm{n} 1}}{\mathrm{~S}_{n 1}} & \cdots & \mathrm{c}_{\mathrm{nn}}=\frac{\mathrm{S}_{\mathrm{nn}}}{\mathrm{S}_{n \mathrm{n}}} \\ 1 & \cdots & 1\end{array}\right], \mathrm{S}_{\mathrm{ij}}$ elements of SAM - MX12,

$\mathrm{S}_{\mathrm{ij}}=\sum_{\mathrm{i}=1}^{\mathrm{n}} \mathrm{S}_{\mathrm{ij}}, \mathrm{j}=1, . ., \mathrm{n}$

$d Y_{n}=\mathbb{C}_{n} d Y+d X=\left(\mathbb{I}-\mathbb{C}_{n}\right)^{-1} d X=\mathbb{M}_{C} d X$

$\mathbb{M}_{\mathrm{C}}=\mathbb{R} \mathbb{D}$;

$\mathbb{R}$ is distribution effect $y \mathbb{D}$ is interdependence effect

Rearranging terms

$\mathbb{D}=\left(\mathbb{I}-\mathrm{C}_{22}\right)^{-1} \mathrm{C}_{21} \mathrm{C}_{13}\left(\mathbb{I}-\mathrm{C}_{33}\right)^{-1}=\mathbb{D}_{3} \mathbb{D}_{2} \mathbb{D}_{1} ;$

$\mathbb{D}_{1}=\left(\mathbb{I}-\mathrm{C}_{33}\right)^{-1}$ intersectoral production effect,

$\mathbb{D}_{2}=\mathrm{C}_{21} \mathrm{C}_{13}$ direct distributional effects,

$\mathbb{D}_{3}=\left(\mathbb{I}-\mathrm{C}_{22}\right)^{-1}$ Transfer effects

$$
\mathbb{R}=\left[\mathbb{I}+\left(\mathbb{I}-\mathrm{C}_{22}\right)^{-1} \mathrm{C}_{21} \mathrm{C}_{13}\left(\mathbb{I}-\mathrm{C}_{33}\right)^{-1} \mathrm{C}_{32}\right]^{-1}=[\mathbb{I}+\mathbb{D} \mathbb{E}]^{-1}
$$$$
\mathbb{E}=\mathrm{C}_{32}
$$$$
\mathbb{M}_{\mathrm{C} 23}=\mathbb{R} \mathbb{D}=[\mathbb{I}+\mathbb{D E}]^{-1} \mathbb{D}
$$

The Foster-Green-Thorbecke index, $\mathrm{Pa}$, is well known [8,9] and serves to analyze poverty. If $\alpha=0$ is known as counting. For $\alpha=1$ as the poverty gap and $\alpha=2$ sensitivity. The sensitivity of poverty is determined by the elasticity of the selected poverty measure with respect to the median income by the various groups of households and their rates of growth.

$$
\begin{aligned}
& \mathrm{dP}_{\alpha \mathrm{ij}}=\frac{\partial \mathrm{P}_{\alpha \mathrm{ij}}}{\partial \mathrm{y}_{\mathrm{i}}} \mathrm{d} \mathrm{y}_{\mathrm{i}}+\sum_{\mathrm{k}=1}^{1} \frac{\partial \mathrm{P}_{\alpha \mathrm{ij}}}{\partial \theta_{\mathrm{ijk}}} \mathrm{d} \theta_{\mathrm{ijk}} \\
& \mathrm{P}_{\alpha \mathrm{ij}} \text { is } \mathrm{F}-\mathrm{G}-\mathrm{TP}_{\alpha} \text { index for sector } \mathrm{j} \text { and group of households } \mathrm{i}
\end{aligned}
$$

$y_{i}$ is the average per capita income of the household group i;

$\theta_{\mathrm{ijk}}$ are the parameters of the income distribution.

The first term after equality is the change in average per capita income relative to the change in production in sector $j$. The second term is the change in income distribution.

An important assumption in this characterization is that the change in output of activity $j$ is distributionally neutral such that

$$
\frac{d P_{\alpha i j}}{P_{\alpha i j}}=\eta_{\alpha i}\left(\frac{d \overline{y_{i}}}{-y_{i}}\right)=\eta_{\alpha i} m_{i j}\left(\frac{d x_{j}}{\bar{y}_{i}}\right), d \overline{y_{i}}=m_{i j}^{*} d x_{j}
$$

$\eta_{\alpha \mathrm{i}}$ is elasticity of $\mathrm{P}_{\alpha \mathrm{ij}}$ respect to the per capita mean of each group of households and a result of the increase in the production of sector $j$;

dy fix price multiplier.

The definition of aggregate poverty is as follows:

$P_{\alpha j}=\sum_{i=1}^{m} P_{\alpha i j}\left(\frac{n_{i}}{n}\right)$

$\sum_{i=1}^{m} n_{i}=n($ total population $), n_{i}$ Population in the - th group

$\frac{d P_{\alpha j}}{P_{\alpha j}}=\sum_{i=1}^{m}\left(\frac{d P_{\alpha i j}}{P_{\alpha j}}\right)\left(\frac{n_{i}}{n}\right)=\sum_{i=1}^{m}\left(\frac{d P_{\alpha i j}}{P_{\alpha i j}}\right)\left(\frac{P_{\alpha i j} n_{i}}{P_{\alpha j} n}\right)=\sum_{i=1}^{m}\left(\frac{d P_{\alpha i j}}{P_{\alpha i j}}\right) S_{\alpha i}$

$\frac{\sum_{k=1}^{q_{i}}\left(\frac{z-y_{k}}{z}\right)^{\alpha}}{\sum_{l=1}^{q_{i}}\left(\frac{z-y_{l}}{z}\right)^{\alpha}}=S_{\alpha i}$

$q_{i}$ number of poor in the i-th group

$\sum_{i=1}^{m} q_{i}=q$ total number of poor

Another assumption in this modeling is that there is a poverty limit on the i-th group. Let $S_{\alpha i}$ be those above the limit of that group.

$$
\begin{aligned}
& \sum_{i=1}^{m} S_{\alpha i}=1 ; S_{\alpha i}=\frac{\sum_{k=1}^{q_{i}}\left(\frac{z-y_{k}}{z}\right)^{\alpha}}{\sum_{l=1}^{q_{i}}\left(\frac{z-y_{l}}{z}\right)^{\alpha}} \\
& \Rightarrow \frac{d P_{\alpha j}}{P_{\alpha j}}=\sum_{i=1}^{m}\left(\frac{d P_{\alpha i j}}{P_{\alpha i j}}\right) S_{\alpha i}=\sum_{i=1}^{m} S_{\alpha i} \eta_{\alpha i} m_{\alpha i}\left(\frac{d x_{j}}{y_{i}}\right)=\sum_{i=1}^{m} m^{\prime}{ }_{\alpha i j} q_{\alpha i j} \\
& m_{\alpha i j}^{\prime} \text { modified indicator. } \quad m_{\alpha i j}^{\prime}=S_{\alpha i} m_{\alpha i}
\end{aligned}
$$

Part of the $m_{i j}$ indicator that contributes to the increase of income of poverty in the $i$ th group.

$$
q_{\alpha i j}=\eta_{\alpha i}\left(\frac{d x_{j}}{y_{i}}\right)
$$

It represents the sensitivity of $\mathrm{P}_{\alpha}$ to the change in income called "effect to the sensitivity of poverty".

Like

$$
m_{i j}=r_{i k} \cdot d_{k j}
$$


Citation: Ledesma-Carrión DE, Hernández-Hernández L (2017) Is the Poverty of the Country a Consequence of the Structure of the Mexican Economy? Int J Account Res 5: 163. doi:10.4172/2472-114X.1000163

Page 6 of 14

$$
\frac{d P_{\alpha j}}{P_{\alpha j}}=r_{\alpha i k} \cdot d_{3 \alpha k j} \cdot d_{2 \alpha j l} \cdot d_{1 \alpha l m} \cdot q_{\alpha m j}
$$

In other words, the total effects of poverty alleviation on the increase in production in sector $j$ consists of the product of two components: 1) the average income change of the poor in all groups of households $\left(m_{\alpha j}\right)$; and 2) the sensitivity of the measure of poverty $\left(q_{\alpha j}\right)$. The welfare income line is defined as the equivalent of the total value of the food basket and the non-food basket per person per month. The minimum welfare line equals the value of the food basket per person per month. The poverty rate of Foster-Greer and Thorbecke, FGT $(\alpha=0)$ is the number of people living in poverty. The FGT index $(\alpha=1)$ is a measure of the average gap to the welfare or minimum welfare line, as appropriate depth measure. The FGT index $(\alpha=2)$ is a measure of the squared average gaps or intensity measure [15].

We consider six scenarios: for each $\alpha(=0,1$ and 2$)$ is applied to the minimum welfare and welfare line. CONEVAL establishes for 2012 [15] that the population with income below the minimum welfare line is $20.0457391189998 \%$ with respect to the total population, that is, 23 '514,885 people and the population with income below the welfare line is $51.6413926154648 \%$ or 60578,530 people. The average monthly income per capita in rural areas is $\$ 790.63$ and in urban areas of $\$ 1,112.60$ for the population with income in the minimum welfare line. Similarly, for the population with income in the welfare line in both areas are $\$ 1,483.68$ and $\$ 2,322.79$, respectively. In addition, FGT poverty rates are calculated in relation to welfare lines for deciles I to $\mathrm{V}$ (Table 1).

\section{Results}

Comparing the total per capita income per decile with the corresponding one reported by CONEVAl [15] in the welfare lines for the rural and urban population, the percentages of the population in each situation are obtained, (Table 2).

Approximating the derivative of the poverty index by the increase of the same one obtains the Table 3 elasticities with respect to the parameters $\alpha$ and decil of income. The same for the case of income.

With this information only the substitutions are made in the cases of interest of equation 2.

$$
\frac{\Delta P_{\alpha i j}}{P_{\alpha i j}}=\eta_{\alpha i}\left(\frac{\Delta \bar{y}_{i}}{-y_{i}}\right)=\eta_{\alpha i} m_{i j}\left(\frac{\Delta x_{j}}{\overline{y_{i}}}\right), \Delta \bar{y}_{i}=m_{i j}^{*} \Delta x_{j}
$$

$$
\begin{aligned}
& \text { And as } \\
& \left\{m_{i j}\right\}=\mathbb{M}_{C 23}=\mathbb{R D}=\mathbb{R} \mathbb{D}_{1} \mathbb{D}_{2} \mathbb{D}_{3}
\end{aligned}
$$

The decomposition is obtained by the distributional and transfer effects. Since the matrix of social accounting from the beginning was disaggregated into deciles of income in the relevant cells.

\begin{tabular}{|c|c|c|c|c|c|c|}
\hline \multicolumn{3}{|c|}{ FGT INDEX } & \multicolumn{2}{|c|}{ Minimum welfare line } & \multicolumn{2}{|c|}{ Welfare line } \\
\hline & & Decil & Rural & Urban & Rural & Urban \\
\hline \multirow[t]{2}{*}{ FGT } & $\alpha=0$ & 1 & 0.076 & 0.044 & 0.039 & 0.067 \\
\hline & & II & & 0.081 & 0.038 & 0.065 \\
\hline \multirow[t]{13}{*}{2012} & & III & & & 0.069 & 0.058 \\
\hline & & IV & & & & 0.06 \\
\hline & & $\mathrm{V}$ & & & & 0.12 \\
\hline & $\alpha=1$ & I & 0.036 & 0.027 & 0.028 & 0.055 \\
\hline & & II & & 0.016 & 0.015 & 0.04 \\
\hline & & III & & & 0.011 & 0.027 \\
\hline & & IV & & & & 0.018 \\
\hline & & $\mathrm{V}$ & & & & 0.017 \\
\hline & $\alpha=2$ & 1 & 0.017 & 0.017 & 0.02 & 0.045 \\
\hline & & II & & 0.003 & 0.006 & 0.025 \\
\hline & & III & & & 0.002 & 0.012 \\
\hline & & IV & & & & 0.006 \\
\hline & & $\mathrm{V}$ & & & & 0.002 \\
\hline \multirow[t]{2}{*}{ FGT } & $\alpha=0$ & 1 & 0.081 & 0.069 & 0.071 & 0.119 \\
\hline & & II & & 0.044 & 0.046 & 0.076 \\
\hline \multirow[t]{13}{*}{2010} & & III & & & 0.036 & 0.061 \\
\hline & & IV & & & & 0.057 \\
\hline & & $\mathrm{V}$ & & & & 0.055 \\
\hline & $\alpha=1$ & 1 & 0.037 & 0.042 & 0.051 & 0.097 \\
\hline & & II & & 0.006 & 0.017 & 0.046 \\
\hline & & III & & & 0.004 & 0.027 \\
\hline & & IV & & & & 0.015 \\
\hline & & $\mathrm{V}$ & & & & 0.005 \\
\hline & $\alpha=2$ & 1 & 0.017 & 0.026 & 0.037 & 0.08 \\
\hline & & II & & 0.001 & 0.006 & 0.028 \\
\hline & & III & & & 0.0004 & 0.012 \\
\hline & & IV & & & & 0.004 \\
\hline & & $\mathrm{V}$ & & & & 0.0005 \\
\hline
\end{tabular}

The results of three industries are shown: Manufacture of products of petroleum and coal, manufacture of parts for motor vehicles and basic steel industry. All for $\Delta \mathrm{x}_{\mathrm{i}}=1$.

Table 1: FGT poverty indexes for welfare lines. Own elaboration based on the income distribution of the ENIGH. 
Citation: Ledesma-Carrión DE, Hernández-Hernández L (2017) Is the Poverty of the Country a Consequence of the Structure of the Mexican Economy? Int J Account Res 5: 163. doi:10.4172/2472-114X.1000163

Page 7 of 14

\begin{tabular}{|c|c|c|c|c|}
\hline \multirow{2}{*}{$\begin{array}{c}\text { \% Total population } 2010 \\
\text { Deciles }\end{array}$} & \multicolumn{2}{|c|}{ Population with income below the minimum welfare line } & \multicolumn{2}{|c|}{ Population with income below the welfare line } \\
\hline & Rural & Urban & Rural & Urban \\
\hline I & 0.081 & 0.069 & 0.071 & 0.119 \\
\hline II & & 0.044 & 0.046 & 0.076 \\
\hline III & & & 0.036 & 0.061 \\
\hline IV & & & & 0.057 \\
\hline $\mathrm{V}$ & & & & 0.055 \\
\hline \% Total population 2012 & $\begin{array}{l}\text { Population with income below } \\
\text { the minimum welfare line }\end{array}$ & & $\begin{array}{l}\text { Population with income below } \\
\text { the welfare line }\end{array}$ & \\
\hline DECILES & RURAL & URBAN & RURAL & URBAN \\
\hline 1 & 0.076 & 0.044 & 0.039 & 0.067 \\
\hline II & & 0.081 & 0.038 & 0.065 \\
\hline III & & & 0.069 & 0.058 \\
\hline IV & & & & 0.06 \\
\hline $\mathrm{V}$ & & & & 0.12 \\
\hline
\end{tabular}

Table 2: Percentage of the Mexican population in poverty with income below the welfare lines per deciles.

\begin{tabular}{|c|c|c|c|c|}
\hline \multirow{3}{*}{$\begin{array}{l}2012 \\
\text { Decil }\end{array}$} & \multicolumn{4}{|c|}{ naij =( $\Delta$ Paij $/ P \alpha \mathbf{i j})(\bar{y} \mathbf{i} / \Delta \overline{\mathbf{y}} \mathbf{i})$} \\
\hline & \multicolumn{2}{|c|}{ Minimum welfare line } & \multicolumn{2}{|c|}{ Welfare line } \\
\hline & Rural & Urban & Rural & Urban \\
\hline \multicolumn{5}{|l|}{$\alpha=0$} \\
\hline I & -0.7565 & -6.3492 & -9.1478 & -8.5669 \\
\hline II & & 9.7328 & -4.3727 & -3.6326 \\
\hline III & & & 11.668 & -1.004 \\
\hline IV & & & & 1.5199 \\
\hline V & & & & 16.8341 \\
\hline \multicolumn{5}{|l|}{$\alpha=1$} \\
\hline 1 & -0.3435 & -6.1175 & -9.1374 & -8.6192 \\
\hline II & & 13.1095 & -2.4611 & -3.0865 \\
\hline III & & & 15.6791 & 0.2533 \\
\hline IV & & & & 4.4486 \\
\hline V & & & & 21.3285 \\
\hline \multicolumn{5}{|l|}{$\alpha=2$} \\
\hline 1 & 0.0552 & -5.8888 & -9.1271 & -8.6717 \\
\hline II & & 15.5143 & -0.691 & -2.5522 \\
\hline III & & & 18.4582 & 1.4491 \\
\hline IV & & & & 7.0608 \\
\hline $\mathrm{V}$ & & & & 24.3987 \\
\hline
\end{tabular}

Table 3: Elasticities by decile of household income for $\alpha=0,1,2$.

Testing with various income-expenditure distributions of households results that the same branches of economic activity are those that more or less impact on poverty alleviation [19-21]. And the multipliers are of the same order of magnitude.

\section{Analysis and Discussion}

For the branches of economic activity that most impact on poverty alleviation, we observe: In the line of minimum welfare for the rural and urban population, poverty alleviation is only in decile I, while in the population below the welfare line it is in deciles I and II for rural and I, II and III for the urban zone. For the urban population below the minimum welfare line mitigation is at least an order of magnitude higher than in the rural area. The same for the decile III in the case of the population below the welfare line, but for deciles I and II are almost of the same magnitude for both rural and urban areas. Similarly for those branches of economic activity that least impact (Tables 4 and 5).

Poverty in decile I is marked with respect to the decile II in the branches that most mitigate poverty and with respect to the decile III in the branches of economic activity that least alleviate poverty and are similar between deciles I and II. This shows the enormous social inequality still among the lowest deciles of income and the differences between rural and urban zones (Tables 6 and 7).

The population below the welfare line, it is more sensitive to poverty in decile I in both rural and urban areas and in decile II in the urban area for the economic activities that least impact. While in the branches of economic activity that most mitigate poverty, it is in the decile I the greatest sensitivity in both urban and rural areas. And for the population with incomes below the welfare line, the decile II in urban areas the sensitivity to poverty is higher than in rural areas (Tables 8 and 9).

\section{Conclusion}

The results show that poverty is related to the structure of the Mexican economy. That is why the permits given by the government to informal traders is a kind of corruption as it is not reflected in the tax system. More than $50 \%$ of the population work in the informal sector. In addition, in this decade the most requested jobs are those related to the provision of services in the health sector. Unlike in branches 
Citation: Ledesma-Carrión DE, Hernández-Hernández L (2017) Is the Poverty of the Country a Consequence of the Structure of the Mexican Economy? Int J Account Res 5: 163. doi:10.4172/2472-114X.1000163

\begin{tabular}{|c|c|c|c|c|c|c|c|}
\hline \multirow{4}{*}{$\begin{array}{c}\alpha=0 \\
\text { Code } \\
\text { NAICS }\end{array}$} & \multirow[t]{4}{*}{ Economic activity/decil } & \multicolumn{6}{|c|}{ Economic activities that most alleviate poverty } \\
\hline & & \multirow{3}{*}{$\begin{array}{c}\text { Rural } \\
\begin{array}{c}\text { Minimum welfare } \\
\text { line }\end{array} \\
\text { D1 }\end{array}$} & \multirow{2}{*}{\multicolumn{2}{|c|}{\begin{tabular}{|c|} 
Urban \\
$\begin{array}{c}\text { Minimum welfare } \\
\text { line }\end{array}$ \\
\end{tabular}}} & \multirow{2}{*}{\multicolumn{3}{|c|}{$\begin{array}{c}\text { Rural } \\
\text { Welfare line }\end{array}$}} \\
\hline & & & & & & & \\
\hline & & & D1 & D2 & D1 & D2 & D3 \\
\hline 6231 & Nursing Care Facilities (Skilled Nursing Facilities) & -0.0017 & -0.01406 & 0.010071 & -0.02025 & -0.00453 & 0.008587 \\
\hline 6117 & Education support services & -0.0017 & -0.01404 & 0.01006 & -0.02023 & -0.00452 & 0.008577 \\
\hline 9321 & International and extraterritorial organizations and bodies & -0.0017 & -0.01401 & 0.010039 & -0.02019 & -0.00451 & 0.008559 \\
\hline 6115 & Trade Schools & -0.0017 & -0.01401 & 0.010037 & -0.02018 & -0.00451 & 0.008558 \\
\hline 6114 & Commercial, computer and executive training schools & -0.0017 & -0.01397 & 0.010008 & -0.02013 & -0.0045 & 0.008533 \\
\hline 4879 & Other tourist transport & -0.0017 & -0.01396 & 0.010002 & -0.02011 & -0.00449 & 0.008528 \\
\hline 5225 & Services related to non-stock exchange credit intermediation & -0.0017 & -0.01391 & 0.009968 & -0.02004 & -0.00448 & 0.008499 \\
\hline 7213 & $\begin{array}{l}\text { Pensions and guesthouses, and apartments and houses furnished with hotel } \\
\text { services }\end{array}$ & -0.0017 & -0.0139 & 0.009962 & -0.02003 & -0.00448 & 0.008494 \\
\hline 6214 & Centers for the care of patients who do not require hospitalization & -0.0017 & -0.01389 & 0.009949 & -0.02001 & -0.00447 & 0.008483 \\
\hline 6233 & Nursing home and other nursing homes & -0.0017 & -0.01388 & 0.009944 & -0.02 & -0.00447 & 0.008478 \\
\hline 6213 & Other health care practices & -0.0017 & -0.01388 & 0.009943 & -0.02 & -0.00447 & 0.008478 \\
\hline 4855 & Bus hire with driver & -0.0016 & -0.01374 & 0.009841 & -0.01979 & -0.00442 & 0.00839 \\
\hline 4812 & Not Regular air transport & -0.0016 & -0.01366 & 0.009787 & -0.01968 & -0.0044 & 0.008344 \\
\hline 5617 & Cleaning services & -0.0016 & -0.01359 & 0.009738 & -0.01958 & -0.00438 & 0.008303 \\
\hline 4832 & Inland water transport & -0.0016 & -0.01359 & 0.009737 & -0.01958 & -0.00438 & 0.008302 \\
\hline 4854 & School and personnel transportation & -0.0016 & -0.0135 & 0.009672 & -0.01945 & -0.00435 & 0.008246 \\
\hline 7212 & Camps and recreational shelters & -0.0016 & -0.01345 & 0.009633 & -0.01937 & -0.00433 & 0.008214 \\
\hline 5414 & Specialized design & -0.0016 & -0.01334 & 0.009558 & -0.01922 & -0.00429 & 0.00815 \\
\hline 5614 & $\begin{array}{l}\text { Secretarial support service, photocopying, collection, credit investigation and } \\
\text { similar }\end{array}$ & -0.0016 & -0.01329 & 0.00952 & -0.01915 & -0.00428 & 0.008117 \\
\hline 6216 & Nursing services at home & -0.0016 & -0.01326 & 0.009501 & -0.01911 & -0.00427 & 0.008101 \\
\hline \multirow{3}{*}{$\begin{array}{l}\alpha=0 \\
\text { Code } \\
\text { NAICS }\end{array}$} & \multirow[t]{3}{*}{ Economic activity/decil } & \multicolumn{6}{|c|}{ Economic activities that most alleviate poverty } \\
\hline & & \multicolumn{6}{|c|}{$\begin{array}{l}\text { Urban } \\
\text { Welfare line }\end{array}$} \\
\hline & & D1 & D2 & D3 & D4 & D5 & \\
\hline 6231 & Nursing Care Facilities (Skilled Nursing Facilities) & -0.01897 & -0.00376 & -0.00074 & 0.000871 & 0.007764 & \\
\hline 6117 & Education support services & -0.01895 & -0.00376 & -0.00074 & 0.00087 & 0.007756 & \\
\hline 9321 & International and extraterritorial organizations and bodies & -0.01891 & -0.00375 & -0.00074 & 0.000868 & 0.00774 & \\
\hline 6115 & Trade Schools & -0.0189 & -0.00375 & -0.00074 & 0.000868 & 0.007739 & \\
\hline 6114 & Commercial, computer and executive training schools & -0.01885 & -0.00374 & -0.00073 & 0.000865 & 0.007716 & \\
\hline 4879 & Other tourist transport & -0.01884 & -0.00373 & -0.00073 & 0.000865 & 0.007711 & \\
\hline 5225 & Services related to non-stock exchange credit intermediation & -0.01877 & -0.00372 & -0.00073 & 0.000862 & 0.007685 & \\
\hline 7213 & $\begin{array}{l}\begin{array}{l}\text { Pensions and guesthouses, and apartments and houses furnished with hotel } \\
\text { services }\end{array}\end{array}$ & -0.01876 & -0.00372 & -0.00073 & 0.000861 & 0.00768 & \\
\hline 6214 & Centers for the care of patients who do not require hospitalization & -0.01874 & -0.00371 & -0.00073 & 0.00086 & 0.00767 & \\
\hline 6233 & Nursing home and other nursing homes & -0.01873 & -0.00371 & -0.00073 & 0.00086 & 0.007667 & \\
\hline 6213 & Other health care practices & -0.01873 & -0.00371 & -0.00073 & 0.00086 & 0.007666 & \\
\hline 4855 & Bus hire with driver & -0.01853 & -0.00367 & -0.00072 & 0.000851 & 0.007587 & \\
\hline 4812 & Not Regular air transport & -0.01843 & -0.00365 & -0.00072 & 0.000846 & 0.007545 & \\
\hline 5617 & Cleaning services & -0.01834 & -0.00364 & -0.00071 & 0.000842 & 0.007508 & \\
\hline 4832 & Inland water transport & -0.01834 & -0.00363 & -0.00071 & 0.000842 & 0.007507 & \\
\hline 4854 & School and personnel transportation & -0.01821 & -0.00361 & -0.00071 & 0.000836 & 0.007457 & \\
\hline 7212 & Camps and recreational shelters & -0.01814 & -0.0036 & -0.00071 & 0.000833 & 0.007427 & \\
\hline 5414 & Specialized design & -0.018 & -0.00357 & -0.0007 & 0.000826 & 0.007369 & \\
\hline 5614 & $\begin{array}{l}\text { Secretarial support service, photocopying, collection, credit investigation and } \\
\text { similar }\end{array}$ & -0.01793 & -0.00355 & -0.0007 & 0.000823 & 0.00734 & \\
\hline 6216 & Nursing services at home & -0.01789 & -0.00355 & -0.0007 & 0.000821 & 0.007325 & \\
\hline & & & & & & & \\
\hline
\end{tabular}

Table 4: Branches of economic activity that most impact on the alleviation of poverty in the rural and urban population for the lines of well-being by household income decile. 
Citation: Ledesma-Carrión DE, Hernández-Hernández L (2017) Is the Poverty of the Country a Consequence of the Structure of the Mexican Economy? Int J Account Res 5: 163. doi:10.4172/2472-114X.1000163

Page 9 of 14

\begin{tabular}{|c|c|c|c|c|c|c|c|}
\hline \multirow{4}{*}{$\begin{array}{c}\alpha=0 \\
\text { Code } \\
\text { NAICS }\end{array}$} & \multirow[t]{4}{*}{ Economic activity/Decil } & \multicolumn{6}{|c|}{ Economic activities that least alleviate poverty } \\
\hline & & \multirow{3}{*}{$\begin{array}{c}\text { Rural } \\
\begin{array}{c}\text { Minimum } \\
\text { welfare line }\end{array} \\
\text { D1 }\end{array}$} & \multirow{2}{*}{\multicolumn{2}{|c|}{$\begin{array}{c}\text { Urban } \\
\text { Minimum welfare line }\end{array}$}} & \multirow{2}{*}{\multicolumn{3}{|c|}{$\begin{array}{c}\text { Rural } \\
\text { Welfare line }\end{array}$}} \\
\hline & & & & & & & \\
\hline & & & D1 & D2 & D1 & D2 & D3 \\
\hline 3311 & Basic iron and steel industry & -0.00026 & -0.00218 & 0.001561 & -0.00314 & -0.0007 & 0.001331 \\
\hline 3321 & Manufacture of forged and die-cut metal products & -0.00026 & -0.00218 & 0.001561 & -0.00314 & -0.0007 & 0.001331 \\
\hline 3329 & Manufacture of other fabricated metal products & -0.00026 & -0.00215 & 0.001537 & -0.00309 & -0.00069 & 0.00131 \\
\hline 3326 & Manufacture of wire, wire products and springs & -0.00026 & -0.00214 & 0.001535 & -0.00309 & -0.00069 & 0.001309 \\
\hline 3259 & Manufacture of other chemical products & -0.00025 & -0.00212 & 0.001521 & -0.00306 & -0.00068 & 0.001296 \\
\hline 4841 & General cargo haulage & -0.00025 & -0.00208 & 0.001488 & -0.00299 & -0.00067 & 0.001269 \\
\hline 3222 & Manufacture of paperboard and paper products & -0.00025 & -0.00206 & 0.001475 & -0.00297 & -0.00066 & 0.001258 \\
\hline 3256 & Manufacture of soap, cleaners and toilet preparations & -0.00025 & -0.00206 & 0.001475 & -0.00297 & -0.00066 & 0.001258 \\
\hline 3323 & Manufacture of metal structures and products of blacksmithing & -0.00025 & -0.00206 & 0.001474 & -0.00296 & -0.00066 & 0.001257 \\
\hline 3152 & Manufacture of wearing apparel & -0.00024 & -0.00205 & 0.001471 & -0.00296 & -0.00066 & 0.001255 \\
\hline 3313 & Basic aluminum industry & -0.00024 & -0.00204 & 0.001462 & -0.00294 & -0.00066 & 0.001246 \\
\hline 3345 & $\begin{array}{l}\text { Manufacture of measuring, control, navigation and electronic } \\
\text { medical equipment }\end{array}$ & -0.00024 & -0.00203 & 0.001458 & -0.00293 & -0.00066 & 0.001243 \\
\hline 3325 & Manufacture of fittings and locks & -0.00024 & -0.00201 & 0.001437 & -0.00289 & -0.00065 & 0.001225 \\
\hline 3241 & Manufacture of products of petroleum and coal & -0.00024 & -0.002 & 0.001436 & -0.00289 & -0.00065 & 0.001224 \\
\hline 1153 & Services related to forest harvesting & -0.00024 & -0.002 & 0.001432 & -0.00288 & -0.00064 & 0.001221 \\
\hline 3261 & Manufacture of plastic products & -0.00024 & -0.00199 & 0.001428 & -0.00287 & -0.00064 & 0.001217 \\
\hline 4851 & Urban and suburban public fixed-route passenger transport & -0.00023 & -0.00193 & 0.001386 & -0.00279 & -0.00062 & 0.001181 \\
\hline 3339 & Manufacture of other machinery and equipment for general industry & -0.00023 & -0.00193 & 0.001385 & -0.00279 & -0.00062 & 0.001181 \\
\hline 3399 & Other Manufacturing & -0.00023 & -0.00193 & 0.001379 & -0.00277 & -0.00062 & 0.001176 \\
\hline 3336 & $\begin{array}{l}\text { Manufacture of internal combustion engines, turbines and } \\
\text { transmissions }\end{array}$ & -0.00023 & -0.00191 & 0.00137 & -0.00276 & -0.00062 & 0.001168 \\
\hline 3363 & Manufacture of parts for motor vehicles & -0.00023 & -0.00191 & 0.001368 & -0.00275 & -0.00062 & 0.001167 \\
\hline 3312 & Manufacture of iron and steel products & -0.00022 & -0.00187 & 0.001338 & -0.00269 & -0.0006 & 0.001141 \\
\hline 3342 & Manufacture of communication equipment & -0.00021 & -0.00178 & 0.001277 & -0.00257 & -0.00057 & 0.001088 \\
\hline 3353 & Manufacture of electricity generation and distribution equipment & -0.00021 & -0.00177 & 0.001265 & -0.00254 & -0.00057 & 0.001079 \\
\hline 3361 & Manufacture of cars and trucks & -0.00019 & -0.00161 & 0.001155 & -0.00232 & -0.00052 & 0.000985 \\
\hline 3341 & Manufacture of computers and peripheral equipment & -0.00016 & -0.00132 & 0.000944 & -0.0019 & -0.00042 & 0.000805 \\
\hline 3343 & Manufacture of audio and video equipment & -0.00016 & -0.00131 & 0.000941 & -0.00189 & -0.00042 & 0.000802 \\
\hline \multirow{3}{*}{$\begin{array}{c}\alpha=0 \\
\text { Code } \\
\text { NAICS }\end{array}$} & \multirow[t]{3}{*}{ Economic activity/ Decil } & \multicolumn{6}{|c|}{ Economic activities that least alleviate poverty } \\
\hline & & \multicolumn{6}{|c|}{$\begin{array}{c}\text { Urban } \\
\text { Welfare line }\end{array}$} \\
\hline & & D1 & D2 & D3 & D4 & D5 & \\
\hline 3311 & Basic iron and steel industry & -0.00294 & -0.00058 & -0.00011 & 0.00014 & 0.0012 & \\
\hline 3321 & Manufacture of forged and die-cut metal products & -0.00294 & -0.00058 & -0.00011 & 0.00014 & 0.0012 & \\
\hline 3329 & Manufacture of other fabricated metal products & -0.00289 & -0.00057 & -0.00011 & 0.00013 & 0.00118 & \\
\hline 3326 & Manufacture of wire, wire products and springs & -0.00289 & -0.00057 & -0.00011 & 0.00013 & 0.00118 & \\
\hline 3259 & Manufacture of other chemical products & -0.00286 & -0.00057 & -0.00011 & 0.00013 & 0.00117 & \\
\hline 4841 & General cargo haulage & -0.0028 & -0.00056 & -0.00011 & 0.00013 & 0.00115 & \\
\hline 3222 & Manufacture of paperboard and paper products & -0.00278 & -0.00055 & -0.00011 & 0.00013 & 0.00114 & \\
\hline 3256 & Manufacture of soap, cleaners and toilet preparations & -0.00278 & -0.00055 & -0.00011 & 0.00013 & 0.00114 & \\
\hline 3323 & Manufacture of metal structures and products of blacksmithing & -0.00278 & -0.00055 & -0.00011 & 0.00013 & 0.00114 & \\
\hline 3152 & Manufacture of wearing apparel & -0.00277 & -0.00055 & -0.00011 & 0.00013 & 0.00113 & \\
\hline 3313 & Basic aluminum industry & -0.00275 & -0.00055 & -0.00011 & 0.00013 & 0.00113 & \\
\hline 3345 & $\begin{array}{c}\text { Manufacture of measuring, control, navigation and electronic } \\
\text { medical equipment }\end{array}$ & -0.00275 & -0.00054 & -0.00011 & 0.00013 & 0.00112 & \\
\hline 3325 & Manufacture of fittings and locks & -0.00271 & -0.00054 & -0.00011 & 0.00012 & 0.00111 & \\
\hline 3241 & Manufacture of products of petroleum and coal & -0.0027 & -0.00054 & -0.00011 & 0.00012 & 0.00111 & \\
\hline 1153 & Services related to forest harvesting & -0.0027 & -0.00053 & -0.00011 & 0.00012 & 0.0011 & \\
\hline 3261 & Manufacture of plastic products & -0.00269 & -0.00053 & -0.00011 & 0.00012 & 0.0011 & \\
\hline 4851 & Urban and suburban public fixed-route passenger transport & -0.00261 & -0.00052 & -0.0001 & 0.00012 & 0.00107 & \\
\hline 3339 & Manufacture of other machinery and equipment for general industry & -0.00261 & -0.00052 & -0.0001 & 0.00012 & 0.00107 & \\
\hline 3399 & Other Manufacturing & -0.0026 & -0.00052 & -0.0001 & 0.00012 & 0.00106 & \\
\hline 3336 & $\begin{array}{l}\text { Manufacture of internal combustion engines, turbines and } \\
\text { transmissions }\end{array}$ & -0.00258 & -0.00051 & -0.0001 & 0.00012 & 0.00106 & \\
\hline 3363 & Manufacture of parts for motor vehicles & -0.00258 & -0.00051 & -0.0001 & 0.00012 & 0.00106 & \\
\hline 3312 & Manufacture of iron and steel products & -0.00252 & -0.0005 & $-9.8 \mathrm{E}-05$ & 0.00012 & 0.00103 & \\
\hline 3342 & Manufacture of communication equipment & -0.0024 & -0.00048 & $-9.4 \mathrm{E}-05$ & 0.00011 & 0.00098 & \\
\hline 3353 & Manufacture of electricity generation and distribution equipment & -0.00238 & -0.00047 & $-9.3 \mathrm{E}-05$ & 0.00011 & 0.00098 & \\
\hline 3361 & Manufacture of cars and trucks & -0.00218 & -0.00043 & $-8.5 \mathrm{E}-05$ & 0.0001 & 0.00089 & \\
\hline 3341 & Manufacture of computers and peripheral equipment & -0.00178 & -0.00035 & $-6.9 \mathrm{E}-05$ & 0.000082 & 0.00073 & \\
\hline 3343 & Manufacture of audio and video equipment & -0.00177 & -0.00035 & $-6.9 \mathrm{E}-05$ & 0.000081 & 0.00073 & \\
\hline & North America industrial Classificati & tem (NAICC & de of 2007. & & & & \\
\hline
\end{tabular}

Table 5: Branches of economic activity that least impacto on the poverty alleviation in the rural and urban population for well-being lines by household income decile. 
Citation: Ledesma-Carrión DE, Hernández-Hernández L (2017) Is the Poverty of the Country a Consequence of the Structure of the Mexican Economy? Int J Account Res 5: 163. doi:10.4172/2472-114X.1000163

Page 10 of 14

\begin{tabular}{|c|c|c|c|c|c|c|c|c|}
\hline \multirow{4}{*}{$\begin{array}{c}\alpha=1 \\
\text { Code } \\
\text { NAICS }\end{array}$} & \multirow{4}{*}{ Economic activity/decil } & \multicolumn{7}{|c|}{ Economic activities that most alleviate poverty } \\
\hline & & \multirow{3}{*}{\multicolumn{2}{|c|}{$\begin{array}{c}\text { Rural } \\
\begin{array}{c}\text { Minimum welfare } \\
\text { line }\end{array} \\
\text { D1 }\end{array}$}} & \multirow{2}{*}{\multicolumn{2}{|c|}{$\begin{array}{l}\text { Urban } \\
\text { mum welfare } \\
\text { line }\end{array}$}} & \multirow{2}{*}{\multicolumn{3}{|c|}{$\begin{array}{c}\text { Rural } \\
\text { Welfare line }\end{array}$}} \\
\hline & & & & & & & & \\
\hline & & & & \begin{tabular}{l|l} 
D1 & \\
& -1
\end{tabular} & D2 & D1 & D2 & D3 \\
\hline 6231 & Nursing Care Facilities (Skilled Nursing Facilities) & \multicolumn{2}{|c|}{-0.00076} & -0.01354 & 0.013565 & -0.02023 & -0.00255 & 0.011538 \\
\hline 6117 & Education support services & \multicolumn{2}{|c|}{-0.00076} & -0.01353 & 0.01355 & -0.02021 & -0.00254 & 0.011526 \\
\hline 9321 & International and extraterritorial organizations and bodies & \multicolumn{2}{|c|}{-0.00076} & -0.0135 & 0.013522 & -0.02016 & -0.00254 & 0.011502 \\
\hline 6115 & Trade Schools & \multicolumn{2}{|c|}{-0.00076} & -0.0135 & 0.01352 & -0.02016 & -0.00254 & 0.0115 \\
\hline 6114 & Commercial, computer and executive training schools & \multicolumn{2}{|c|}{-0.00076} & -0.01346 & 0.013481 & -0.0201 & -0.00253 & 0.011467 \\
\hline 4879 & Other tourist transport & \multicolumn{2}{|c|}{-0.00076} & -0.01345 & 0.013472 & -0.02009 & -0.00253 & 0.01146 \\
\hline 5225 & Services related to non-stock exchange credit intermediation & \multicolumn{2}{|c|}{-0.00075} & -0.01341 & 0.013426 & -0.02002 & -0.00252 & 0.01142 \\
\hline 7213 & $\begin{array}{l}\text { Pensions and guesthouses, and apartments and houses furnished with hotel } \\
\text { services }\end{array}$ & \multicolumn{2}{|c|}{-0.00075} & -0.0134 & 0.013418 & -0.02001 & -0.00252 & 0.011413 \\
\hline 6214 & Centers for the care of patients who do not require hospitalization & \multicolumn{2}{|c|}{-0.00075} & -0.01338 & 0.0134 & -0.01998 & -0.00252 & 0.011399 \\
\hline 6233 & Nursing home and other nursing homes & \multicolumn{2}{|c|}{-0.00075} & -0.01337 & 0.013394 & -0.01997 & -0.00251 & 0.011393 \\
\hline 6213 & Other health care practices & \multicolumn{2}{|c|}{-0.00075} & -0.01337 & 0.013393 & -0.01997 & -0.00251 & 0.011392 \\
\hline 4855 & Bus hire with driver & \multicolumn{2}{|c|}{-0.00074} & -0.01323 & 0.013255 & -0.01977 & -0.00249 & 0.011275 \\
\hline 4812 & Not Regular air transport & \multicolumn{2}{|c|}{-0.00074} & -0.01316 & 0.013182 & -0.01966 & -0.00248 & 0.011213 \\
\hline 5617 & Cleaning services & \multicolumn{2}{|c|}{-0.00074} & -0.0131 & 0.013116 & -0.01956 & -0.00246 & 0.011157 \\
\hline 4832 & Inland water transport & \multicolumn{2}{|c|}{-0.00074} & -0.0131 & 0.013115 & -0.01956 & -0.00246 & 0.011156 \\
\hline 4854 & School and personnel transportation & -0.00 & 0073 & -0.01301 & 0.013027 & -0.01943 & -0.00245 & 0.011081 \\
\hline 7212 & Camps and recreational shelters & -0.00 & 0073 & -0.01296 & 0.012975 & -0.01935 & -0.00244 & 0.011037 \\
\hline 5414 & Specialized design & -0.00 & 0074 & -0.0131 & 0.013116 & -0.0192 & -0.00242 & 0.010951 \\
\hline 5614 & $\begin{array}{l}\text { Secretarial support service, photocopying, collection, credit investigation and } \\
\text { similar }\end{array}$ & -0.00 & 0074 & -0.0131 & 0.013115 & -0.01912 & -0.00241 & 0.010908 \\
\hline 6216 & Nursing services at home & -0.00 & 0073 & -0.01301 & 0.013027 & -0.01908 & -0.0024 & 0.010886 \\
\hline $\begin{array}{c}\alpha=1 \\
\text { Code }\end{array}$ & Economic activity/decil & & Econo & omic activitie & es that mos & st alleviate & ooverty & \\
\hline NAICS & & & & & $\begin{array}{l}\text { URBAN } \\
\text { Welfare line }\end{array}$ & & & \\
\hline & & D1 & D2 & D3 & D4 & D5 & & \\
\hline 6231 & Nursing Care Facilities (Skilled Nursing Facilities) & -0.01908 & -0.00319 & 0.000186 & 0.002548 & 0.009837 & & \\
\hline 6117 & Education support services & -0.01906 & -0.00319 & 0.000186 & 0.002546 & 0.009827 & & \\
\hline 9321 & International and extraterritorial organizations and bodies & -0.01902 & -0.00318 & 0.000186 & 0.00254 & 0.009806 & & \\
\hline 6115 & Trade Schools & -0.01902 & -0.00318 & 0.000186 & 0.00254 & 0.009805 & & \\
\hline 6114 & Commercial, computer and executive training schools & -0.01896 & -0.00317 & 0.000185 & 0.002533 & 0.009776 & & \\
\hline 4879 & Other tourist transport & -0.01895 & -0.00317 & 0.000185 & 0.002531 & 0.00977 & & \\
\hline 5225 & Services related to non-stock exchange credit intermediation & -0.01889 & -0.00316 & 0.000185 & 0.002522 & 0.009737 & & \\
\hline 7213 & $\begin{array}{l}\text { Pensions and guesthouses, and apartments and houses furnished with hotel } \\
\text { services }\end{array}$ & -0.01888 & -0.00316 & 0.000184 & 0.002521 & 0.009731 & & \\
\hline 6214 & Centers for the care of patients who do not require hospitalization & -0.01885 & -0.00316 & 0.000184 & 0.002517 & 0.009718 & & \\
\hline 6233 & Nursing home and other nursing homes & -0.01884 & -0.00315 & 0.000184 & 0.002516 & 0.009713 & & \\
\hline 6213 & Other health care practices & -0.01884 & -0.00315 & 0.000184 & 0.002516 & 0.009713 & & \\
\hline 4855 & Bus hire with driver & -0.01865 & -0.00312 & 0.000182 & 0.00249 & 0.009612 & & \\
\hline 4812 & Not Regular air transport & -0.01854 & -0.0031 & 0.000181 & 0.002476 & 0.00956 & & \\
\hline 5617 & Cleaning services & -0.01845 & -0.00309 & 0.00018 & 0.002464 & 0.009512 & & \\
\hline 4832 & Inland water transport & -0.01845 & -0.00309 & 0.00018 & 0.002464 & 0.009512 & & \\
\hline 4854 & School and personnel transportation & -0.01833 & -0.00307 & 0.000179 & 0.002447 & 0.009448 & & \\
\hline 7212 & Camps and recreational shelters & -0.01825 & -0.00306 & 0.000178 & 0.002438 & 0.00941 & & \\
\hline 5414 & Specialized design & -0.01811 & -0.00303 & 0.000177 & 0.002419 & 0.009337 & & \\
\hline 5614 & $\begin{array}{l}\text { Secretarial support service, photocopying, collection, credit investigation and } \\
\text { similar }\end{array}$ & -0.01804 & -0.00302 & 0.000176 & 0.002409 & 0.0093 & & \\
\hline 6216 & Nursing services at home & -0.018 & -0.00301 & 0.000176 & 0.002404 & 0.009281 & & \\
\hline
\end{tabular}

Table 6: Branches of economic activity that most impact on the poverty allivation and social inequality in the rural and urban population for the lines of well-being by household income decile. 
Citation: Ledesma-Carrión DE, Hernández-Hernández L (2017) Is the Poverty of the Country a Consequence of the Structure of the Mexican Economy? Int J Account Res 5: 163. doi:10.4172/2472-114X.1000163

Page 11 of 14

\begin{tabular}{|c|c|c|c|c|c|c|c|}
\hline \multirow{4}{*}{$\begin{array}{c}\alpha=1 \\
\text { Code } \\
\text { NAICS }\end{array}$} & \multirow[t]{4}{*}{ Economic activity/Decil } & \multicolumn{6}{|c|}{ Economic activities that least alleviate poverty } \\
\hline & & \multirow{3}{*}{$\begin{array}{c}\text { Rural } \\
\begin{array}{c}\text { Minimum } \\
\text { welfare line }\end{array} \\
\text { D1 }\end{array}$} & \multirow{2}{*}{\multicolumn{2}{|c|}{$\begin{array}{c}\text { Urban } \\
\text { Minimum welfare line }\end{array}$}} & \multirow{2}{*}{\multicolumn{3}{|c|}{$\begin{array}{c}\text { Rural } \\
\text { Welfare line }\end{array}$}} \\
\hline & & & & & & & \\
\hline & & & D1 & D2 & D1 & D2 & D3 \\
\hline 3311 & Basic iron and steel industry & -0.000118 & -0.0021 & 0.002102 & -0.00088 & -0.00011 & 0.000504 \\
\hline 3321 & Manufacture of forged and die-cut metal products & -0.000118 & -0.0021 & 0.002102 & -0.00076 & $-9.5 \mathrm{E}-05$ & 0.00043 \\
\hline 3329 & Manufacture of other fabricated metal products & -0.000116 & -0.00207 & 0.00207 & -0.00065 & $-8.2 \mathrm{E}-05$ & 0.000371 \\
\hline 3326 & Manufacture of wire, wire products and springs & -0.000116 & -0.00207 & 0.002068 & -0.00085 & -0.00011 & 0.000482 \\
\hline 3259 & Manufacture of other chemical products & -0.000115 & -0.00205 & 0.002048 & -0.00082 & -0.0001 & 0.000465 \\
\hline 4841 & General cargo haulage & -0.000112 & -0.002 & 0.002004 & -0.00117 & -0.00015 & 0.000669 \\
\hline 3222 & Manufacture of paperboard and paper products & -0.000111 & -0.00198 & 0.001987 & -0.00079 & $-9.9 \mathrm{E}-05$ & 0.000449 \\
\hline 3256 & Manufacture of soap, cleaners and toilet preparations & -0.000111 & -0.00198 & 0.001987 & -0.0009 & -0.00011 & 0.000514 \\
\hline 3323 & Manufacture of metal structures and products of blacksmithing & -0.000111 & -0.00198 & 0.001985 & -0.0007 & $-8.8 \mathrm{E}-05$ & 0.000398 \\
\hline 3152 & Manufacture of wearing apparel & -0.000111 & -0.00198 & 0.001982 & -0.00086 & -0.00011 & 0.000488 \\
\hline 3313 & Basic aluminum industry & -0.00011 & -0.00197 & 0.001969 & -0.0004 & $-5.1 \mathrm{E}-05$ & 0.000229 \\
\hline 3345 & $\begin{array}{c}\begin{array}{c}\text { Manufacture of measuring, control, navigation and electronic medical } \\
\text { equipment }\end{array}\end{array}$ & -0.00011 & -0.00196 & 0.001963 & -0.00038 & $-4.8 \mathrm{E}-05$ & 0.000216 \\
\hline 3325 & Manufacture of fittings and locks & -0.000108 & -0.00193 & 0.001935 & -0.00032 & $-4.1 \mathrm{E}-05$ & 0.000185 \\
\hline 3241 & Manufacture of products of petroleum and coal & -0.000108 & -0.00193 & 0.001934 & -0.00111 & -0.00014 & 0.000635 \\
\hline 1153 & Services related to forest harvesting & -0.000108 & -0.00193 & 0.001929 & -0.0007 & $-8.8 \mathrm{E}-05$ & 0.0004 \\
\hline 3261 & Manufacture of plastic products & -0.000108 & -0.00192 & 0.001923 & -0.00061 & $-7.7 \mathrm{E}-05$ & 0.000348 \\
\hline 4851 & Urban and suburban public fixed-route passenger transport & -0.000105 & -0.00186 & 0.001866 & -0.00119 & -0.00015 & 0.000677 \\
\hline 3339 & Manufacture of other machinery and equipment for general industry & -0.000105 & -0.00186 & 0.001866 & -0.00064 & $-8.1 \mathrm{E}-05$ & 0.000367 \\
\hline 3399 & Other Manufacturing & -0.000104 & -0.00186 & 0.001858 & -0.00073 & $-9.2 \mathrm{E}-05$ & 0.000415 \\
\hline 3336 & $\begin{array}{l}\text { Manufacture of internal combustion engines, turbines and } \\
\text { transmissions }\end{array}$ & -0.000103 & -0.00184 & 0.001846 & -0.00073 & $-9.3 \mathrm{E}-05$ & 0.000419 \\
\hline 3363 & Manufacture of parts for motor vehicles & -0.000103 & -0.00184 & 0.001843 & -0.00064 & $-8.1 \mathrm{E}-05$ & 0.000365 \\
\hline 3312 & Manufacture of iron and steel products & -0.000101 & -0.0018 & 0.001803 & -0.00088 & -0.00011 & 0.000502 \\
\hline 3342 & Manufacture of communication equipment & $-9.64 \mathrm{E}-05$ & -0.00172 & 0.00172 & -0.00024 & $-3.1 \mathrm{E}-05$ & 0.000139 \\
\hline 3353 & Manufacture of electricity generation and distribution equipment & $-9.55 \mathrm{E}-05$ & -0.0017 & 0.001704 & -0.00046 & $-5.8 \mathrm{E}-05$ & 0.000265 \\
\hline 3361 & Manufacture of cars and trucks & $-8.72 \mathrm{E}-05$ & -0.00155 & 0.001556 & -0.00067 & $-8.5 \mathrm{E}-05$ & 0.000383 \\
\hline 3341 & Manufacture of computers and peripheral equipment & $-7.13 \mathrm{E}-05$ & -0.00127 & 0.001272 & -0.00034 & $-4.3 \mathrm{E}-05$ & 0.000192 \\
\hline 3343 & Manufacture of audio and video equipment & -0.000071 & -0.00127 & 0.001267 & -0.00016 & $-2 \mathrm{E}-05$ & $8.87 \mathrm{E}-05$ \\
\hline \multirow{3}{*}{$\begin{array}{c}\alpha=1 \\
\text { Code } \\
\text { NAICS }\end{array}$} & \multirow[t]{3}{*}{ Economic activity/Decil } & \multicolumn{6}{|c|}{ Economic activities that least alleviate poverty } \\
\hline & & \multicolumn{6}{|c|}{$\begin{array}{c}\text { Urban } \\
\text { Welfare line }\end{array}$} \\
\hline & & D1 & D2 & D3 & D4 & D5 & \\
\hline 3311 & Basic iron and steel industry & -0.002957 & -0.0005 & 2.89E-05 & 0.000395 & 0.001524 & \\
\hline 3321 & Manufacture of forged and die-cut metal products & -0.002957 & -0.0005 & 2.89E-05 & 0.000395 & 0.001524 & \\
\hline 3329 & Manufacture of other fabricated metal products & -0.002912 & -0.00049 & $2.84 \mathrm{E}-05$ & 0.000389 & 0.001501 & \\
\hline 3326 & Manufacture of wire, wire products and springs & -0.002909 & -0.00049 & 2.84E-05 & 0.000389 & 0.0015 & \\
\hline 3259 & Manufacture of other chemical products & -0.002881 & -0.00048 & $2.81 \mathrm{E}-05$ & 0.000385 & 0.001485 & \\
\hline 4841 & General cargo haulage & -0.002819 & -0.00047 & $2.75 \mathrm{E}-05$ & 0.000377 & 0.001453 & \\
\hline 3222 & Manufacture of paperboard and paper products & -0.002795 & -0.00047 & 2.73E-05 & 0.000373 & 0.001441 & \\
\hline 3256 & Manufacture of soap, cleaners and toilet preparations & -0.002795 & -0.00047 & 2.73E-05 & 0.000373 & 0.001441 & \\
\hline 3323 & Manufacture of metal structures and products of blacksmithing & -0.002792 & -0.00047 & 2.73E-05 & 0.000373 & 0.00144 & \\
\hline 3152 & Manufacture of wearing apparel & -0.002788 & -0.00047 & $2.72 \mathrm{E}-05$ & 0.000372 & 0.001437 & \\
\hline 3313 & Basic aluminum industry & -0.00277 & -0.00046 & $2.71 \mathrm{E}-05$ & 0.00037 & 0.001428 & \\
\hline 3345 & $\begin{array}{l}\text { Manufacture of measuring, control, navigation and electronic } \\
\text { medical equipment }\end{array}$ & -0.002762 & -0.00046 & 2.7E-05 & 0.000369 & 0.001424 & \\
\hline 3325 & Manufacture of fittings and locks & -0.002722 & -0.00046 & $2.66 \mathrm{E}-05$ & 0.000364 & 0.001404 & \\
\hline 3241 & Manufacture of products of petroleum and coal & -0.002721 & -0.00046 & $2.66 \mathrm{E}-05$ & 0.000363 & 0.001403 & \\
\hline 1153 & Services related to forest harvesting & -0.002713 & -0.00045 & $2.65 \mathrm{E}-05$ & 0.000362 & 0.001399 & \\
\hline 3261 & Manufacture of plastic products & -0.002705 & -0.00045 & 2.64E-05 & 0.000361 & 0.001395 & \\
\hline 4851 & Urban and suburban public fixed-route passenger transport & -0.002625 & -0.00044 & 2.57E-05 & 0.000351 & 0.001354 & \\
\hline 3339 & Manufacture of other machinery and equipment for general industry & -0.002624 & -0.00044 & $2.56 \mathrm{E}-05$ & 0.000351 & 0.001353 & \\
\hline 3399 & Other Manufacturing & -0.002613 & -0.00044 & $2.55 \mathrm{E}-05$ & 0.000349 & 0.001347 & \\
\hline 3336 & $\begin{array}{l}\text { Manufacture of internal combustion engines, turbines and } \\
\text { transmissions }\end{array}$ & -0.002596 & -0.00044 & $2.54 \mathrm{E}-05$ & 0.000347 & 0.001338 & \\
\hline 3363 & Manufacture of parts for motor vehicles & -0.002593 & -0.00043 & 2.53E-05 & 0.000346 & 0.001337 & \\
\hline 3312 & Manufacture of iron and steel products & -0.002536 & -0.00042 & $2.48 \mathrm{E}-05$ & 0.000339 & 0.001307 & \\
\hline 3342 & Manufacture of communication equipment & -0.002419 & -0.00041 & $2.36 \mathrm{E}-05$ & 0.000323 & 0.001247 & \\
\hline 3353 & Manufacture of electricity generation and distribution equipment & -0.002397 & -0.0004 & $2.34 \mathrm{E}-05$ & 0.00032 & 0.001236 & \\
\hline 3361 & Manufacture of cars and trucks & -0.002188 & -0.00037 & 2.14E-05 & 0.000292 & 0.001128 & \\
\hline 3341 & Manufacture of computers and peripheral equipment & -0.001789 & -0.0003 & $1.75 \mathrm{E}-05$ & 0.000239 & 0.000922 & \\
\hline 3343 & Manufacture of audio and video equipment & -0.001782 & -0.0003 & $1.74 \mathrm{E}-05$ & 0.000238 & 0.000919 & \\
\hline
\end{tabular}

Table 7: Branches of economic activity that least impact on the poverty alleviation and social inequality in the rural and urban population for well-being lines by household income decile. 
Citation: Ledesma-Carrión DE, Hernández-Hernández L (2017) Is the Poverty of the Country a Consequence of the Structure of the Mexican Economy? Int J Account Res 5: 163. doi:10.4172/2472-114X.1000163

Page 12 of 14

\begin{tabular}{|c|c|c|c|c|c|c|c|}
\hline \multirow{4}{*}{$\begin{array}{c}\alpha=2 \\
\text { Code } \\
\text { NAICS }\end{array}$} & \multirow[t]{4}{*}{ Economic activity /decil } & \multicolumn{6}{|c|}{ Economic activities that most alleviate poverty } \\
\hline & & \multirow{3}{*}{$\begin{array}{c}\text { Rural } \\
\begin{array}{c}\text { Minimum } \\
\text { welfare line }\end{array} \\
\text { D1 }\end{array}$} & \multicolumn{2}{|c|}{ Urban } & \multicolumn{3}{|c|}{ Rural } \\
\hline & & & \multicolumn{2}{|c|}{ Minimum welfare line } & \multicolumn{3}{|c|}{ Welfare line } \\
\hline & & & D1 & D2 & D1 & D2 & D3 \\
\hline 6231 & Nursing Care Facilities (Skilled Nursing Facilities) & 0.000122 & -0.01304 & 0.016053 & -0.02021 & -0.00072 & 0.013584 \\
\hline 6117 & Education support services & 0.000122 & -0.01302 & 0.016036 & -0.02018 & -0.00071 & 0.013569 \\
\hline 9321 & International and extraterritorial organizations and bodies & 0.000122 & -0.013 & 0.016002 & -0.02014 & -0.00071 & 0.01354 \\
\hline 6115 & Trade Schools & 0.000122 & -0.01299 & 0.016 & -0.02014 & -0.00071 & 0.013539 \\
\hline 6114 & Commercial, computer and executive training schools & 0.000121 & -0.01296 & 0.015953 & -0.02008 & -0.00071 & 0.013499 \\
\hline 4879 & Other tourist transport & 0.000121 & -0.01295 & 0.015943 & -0.02007 & -0.00071 & 0.013491 \\
\hline 5225 & Services related to non-stock exchange credit intermediation & 0.000121 & -0.0129 & 0.015889 & -0.02 & -0.00071 & 0.013445 \\
\hline 7213 & $\begin{array}{l}\text { Pensions and guesthouses, and apartments and houses furnished } \\
\text { with hotel services }\end{array}$ & 0.000121 & -0.0129 & 0.015879 & -0.01999 & -0.00071 & 0.013436 \\
\hline 6214 & Centers for the care of patients who do not require hospitalization & 0.000121 & -0.01288 & 0.015858 & -0.01996 & -0.00071 & 0.013419 \\
\hline 6233 & Nursing home and other nursing homes & 0.000121 & -0.01287 & 0.015851 & -0.01995 & -0.00071 & 0.013412 \\
\hline 6213 & Other health care practices & 0.000121 & -0.01287 & 0.01585 & -0.01995 & -0.00071 & 0.013412 \\
\hline 4855 & Bus hire with driver & 0.000119 & -0.01274 & 0.015686 & -0.01974 & -0.0007 & 0.013273 \\
\hline 4812 & Not Regular air transport & 0.000119 & -0.01267 & 0.0156 & -0.01964 & -0.0007 & 0.0132 \\
\hline 5617 & Cleaning services & 0.000118 & -0.01261 & 0.015522 & -0.01954 & -0.00069 & 0.013135 \\
\hline 4832 & Inland water transport & 0.000118 & -0.01261 & 0.015521 & -0.01954 & -0.00069 & 0.013134 \\
\hline 4854 & School and personnel transportation & 0.000117 & -0.01252 & 0.015417 & -0.01941 & -0.00069 & 0.013045 \\
\hline 7212 & Camps and recreational shelters & 0.000117 & -0.01247 & 0.015355 & -0.01933 & -0.00068 & 0.012993 \\
\hline 5414 & Specialized design & 0.000116 & -0.01237 & 0.015236 & -0.01918 & -0.00068 & 0.012893 \\
\hline 5614 & $\begin{array}{l}\text { Secretarial support service, photocopying, collection, credit } \\
\text { investigation and similar }\end{array}$ & 0.000115 & -0.01233 & 0.015176 & -0.0191 & -0.00068 & 0.012841 \\
\hline 6216 & Nursing services at home & 0.000115 & -0.0123 & 0.015145 & -0.01906 & -0.00068 & 0.012815 \\
\hline \multirow{4}{*}{$\begin{array}{c}\alpha=2 \\
\text { Code } \\
\text { NAICS }\end{array}$} & \multirow[t]{4}{*}{ Economic activity/decil } & \multicolumn{6}{|c|}{ Economic activities that most alleviate poverty } \\
\hline & & \multicolumn{6}{|c|}{ URBAN } \\
\hline & & \multicolumn{6}{|c|}{ Welfare line } \\
\hline & & D1 & D2 & D3 & D4 & D5 & \\
\hline 6231 & Nursing Care Facilities (Skilled Nursing Facilities) & -0.0192 & -0.00264 & 0.001066 & 0.004045 & 0.011253 & \\
\hline 6117 & Education support services & -0.01918 & -0.00264 & 0.001065 & 0.00404 & 0.011241 & \\
\hline 9321 & International and extraterritorial organizations and bodies & -0.01914 & -0.00263 & 0.001063 & 0.004032 & 0.011218 & \\
\hline 6115 & Trade Schools & -0.01913 & -0.00263 & 0.001063 & 0.004031 & 0.011216 & \\
\hline 6114 & Commercial, computer and executive training schools & -0.01908 & -0.00262 & 0.00106 & 0.00402 & 0.011184 & \\
\hline 4879 & Other tourist transport & -0.01907 & -0.00262 & 0.001059 & 0.004017 & 0.011177 & \\
\hline 5225 & Services related to non-stock exchange credit intermediation & -0.019 & -0.00261 & 0.001056 & 0.004003 & 0.011138 & \\
\hline 7213 & $\begin{array}{l}\text { Pensions and guesthouses, and apartments and houses furnished } \\
\text { with hotel services }\end{array}$ & -0.01899 & -0.00261 & 0.001055 & 0.004001 & 0.011131 & \\
\hline 6214 & Centers for the care of patients who do not require hospitalization & -0.01897 & -0.00261 & 0.001054 & 0.003996 & 0.011117 & \\
\hline 6233 & Nursing home and other nursing homes & -0.01896 & -0.00261 & 0.001053 & 0.003994 & 0.011112 & \\
\hline 6213 & Other health care practices & -0.01896 & -0.00261 & 0.001053 & 0.003994 & 0.011111 & \\
\hline 4855 & Bus hire with driver & -0.01876 & -0.00258 & 0.001042 & 0.003952 & 0.010996 & \\
\hline 4812 & Not Regular air transport & -0.01866 & -0.00257 & 0.001036 & 0.003931 & 0.010936 & \\
\hline 5617 & Cleaning services & -0.01856 & -0.00255 & 0.001031 & 0.003911 & 0.010881 & \\
\hline 4832 & Inland water transport & -0.01856 & -0.00255 & 0.001031 & 0.003911 & 0.010881 & \\
\hline 4854 & School and personnel transportation & -0.01844 & -0.00254 & 0.001024 & 0.003884 & 0.010808 & \\
\hline 7212 & Camps and recreational shelters & -0.01836 & -0.00253 & 0.00102 & 0.003869 & 0.010764 & \\
\hline 5414 & Specialized design & -0.01822 & -0.00251 & 0.001012 & 0.003839 & 0.010681 & \\
\hline 5614 & $\begin{array}{c}\text { Secretarial support service, photocopying, collection, credit } \\
\text { investigation and similar }\end{array}$ & -0.01815 & -0.0025 & 0.001008 & 0.003824 & 0.010639 & \\
\hline 6216 & Nursing services at home & -0.01811 & -0.00249 & 0.001006 & 0.003816 & 0.010617 & \\
\hline & North America industrial Clas & on System & ICS) code & 2007. & & & \\
\hline
\end{tabular}

Table 8: Branches of economic activity that most impact on the sensitivity of poverty in the rural and urban population for the lines of well-being by household income decile. 
Citation: Ledesma-Carrión DE, Hernández-Hernández L (2017) Is the Poverty of the Country a Consequence of the Structure of the Mexican Economy? Int J Account Res 5: 163. doi:10.4172/2472-114X.1000163

Page 13 of 14

\begin{tabular}{|c|c|c|c|c|c|c|c|}
\hline \multirow{4}{*}{$\begin{array}{c}\alpha=2 \\
\text { Code } \\
\text { NAICS }\end{array}$} & \multirow[t]{4}{*}{ Economic activity/Decil } & \multicolumn{6}{|c|}{ Economic activities that least alleviate poverty } \\
\hline & & \multirow{3}{*}{$\begin{array}{c}\text { Rural } \\
\begin{array}{c}\text { Minimum } \\
\text { welfare line }\end{array} \\
\text { D1 }\end{array}$} & \multirow{2}{*}{\multicolumn{2}{|c|}{$\begin{array}{c}\text { Urban } \\
\text { Minimum welfare line }\end{array}$}} & \multirow{2}{*}{\multicolumn{3}{|c|}{$\begin{array}{c}\text { Rural } \\
\text { Welfare line }\end{array}$}} \\
\hline & & & & & & & \\
\hline & & & D1 & D2 & D1 & D2 & D3 \\
\hline 3311 & Basic iron and steel industry & -0.00202 & -0.00202 & 0.002488 & -0.00313 & -0.000111 & 0.002105 \\
\hline 3321 & Manufacture of forged and die-cut metal products & -0.00202 & -0.00202 & 0.002487 & -0.00313 & -0.000111 & 0.002105 \\
\hline 3329 & Manufacture of other fabricated metal products & -0.00199 & -0.00199 & 0.00245 & -0.00308 & -0.000109 & 0.002073 \\
\hline 3326 & Manufacture of wire, wire products and springs & -0.00199 & -0.00199 & 0.002447 & -0.00308 & -0.000109 & 0.002071 \\
\hline 3259 & Manufacture of other chemical products & -0.00197 & -0.00197 & 0.002424 & -0.00305 & -0.000108 & 0.002051 \\
\hline 4841 & General cargo haulage & -0.00193 & -0.00193 & 0.002372 & -0.00299 & -0.000106 & 0.002007 \\
\hline 3222 & Manufacture of paperboard and paper products & -0.00191 & -0.00191 & 0.002352 & -0.00296 & -0.000105 & 0.00199 \\
\hline 3256 & Manufacture of soap, cleaners and toilet preparations & -0.00191 & -0.00191 & 0.002351 & -0.00296 & -0.000105 & 0.001989 \\
\hline 3323 & Manufacture of metal structures and products of blacksmithing & -0.00191 & -0.00191 & 0.002349 & -0.00296 & -0.000105 & 0.001988 \\
\hline 3152 & Manufacture of wearing apparel & -0.0019 & -0.00191 & 0.002345 & -0.00295 & -0.000104 & 0.001985 \\
\hline 3313 & Basic aluminum industry & -0.00189 & -0.00189 & 0.00233 & -0.00293 & -0.000104 & 0.001972 \\
\hline 3345 & Manufacture of measuring, control, navigation and electronic medical equipment & -0.00189 & -0.00189 & 0.002324 & -0.00293 & -0.000103 & 0.001966 \\
\hline 3325 & Manufacture of fittings and locks & -0.00186 & -0.00186 & 0.00229 & -0.00288 & -0.000102 & 0.001938 \\
\hline 3241 & Manufacture of products of petroleum and coal & -0.00186 & -0.00186 & 0.002289 & -0.00288 & -0.000102 & 0.001937 \\
\hline 1153 & Services related to forest harvesting & -0.00185 & -0.00185 & 0.002282 & -0.00287 & -0.000102 & 0.001931 \\
\hline 3261 & Manufacture of plastic products & -0.00185 & -0.00185 & 0.002276 & -0.00287 & -0.000101 & 0.001926 \\
\hline 4851 & Urban and suburban public fixed-route passenger transport & -0.00179 & -0.00179 & 0.002209 & -0.00278 & -0.0000984 & 0.001869 \\
\hline 3339 & Manufacture of other machinery and equipment for general industry & -0.00179 & -0.00179 & 0.002208 & -0.00278 & -0.0000983 & 0.001868 \\
\hline 3399 & Other Manufacturing & -0.00179 & -0.00179 & 0.002198 & -0.00277 & -0.0000979 & 0.00186 \\
\hline 3336 & Manufacture of internal combustion engines, turbines and transmissions & -0.00177 & -0.00177 & 0.002184 & -0.00275 & -0.0000973 & 0.001848 \\
\hline 3363 & Manufacture of parts for motor vehicles & -0.00177 & -0.00177 & 0.002181 & -0.00275 & -0.0000971 & 0.001846 \\
\hline 3312 & Manufacture of iron and steel products & -0.00173 & -0.00173 & 0.002133 & -0.00269 & -0.000095 & 0.001805 \\
\hline 3342 & Manufacture of communication equipment & -0.00165 & -0.00165 & 0.002035 & -0.00256 & -0.0000906 & 0.001722 \\
\hline 3353 & Manufacture of electricity generation and distribution equipment & -0.00164 & -0.00164 & 0.002017 & -0.00254 & -0.0000898 & 0.001706 \\
\hline 3361 & Manufacture of cars and trucks & -0.0015 & -0.0015 & 0.001841 & -0.00232 & -0.000082 & 0.001558 \\
\hline 3341 & Manufacture of computers and peripheral equipment & -0.00122 & -0.00122 & 0.001505 & -0.00189 & -0.000067 & 0.001273 \\
\hline 3343 & Manufacture of audio and video equipment & -0.00122 & -0.00122 & 0.001499 & -0.00189 & -0.0000668 & 0.001269 \\
\hline \multirow{3}{*}{$\begin{array}{c}\alpha=2 \\
\text { Code } \\
\text { NAICS }\end{array}$} & \multirow[t]{3}{*}{ Economic activity/Decil } & \multicolumn{6}{|c|}{ Economic activities that least alleviate poverty } \\
\hline & & \multicolumn{6}{|c|}{$\begin{array}{c}\text { URBAN } \\
\text { Welfare line }\end{array}$} \\
\hline & & D1 & D2 & D3 & D4 & D5 & \\
\hline 3311 & Basic iron and steel industry & -0.00297 & -0.00041 & 0.000165 & 0.000627 & 0.001744 & \\
\hline 3321 & Manufacture of forged and die-cut metal products & -0.00297 & -0.00041 & 0.000165 & 0.000627 & 0.001744 & \\
\hline 3329 & Manufacture of other fabricated metal products & -0.00293 & -0.0004 & 0.000163 & 0.000617 & 0.001717 & \\
\hline 3326 & Manufacture of wire, wire products and springs & -0.00293 & -0.0004 & 0.000163 & 0.000617 & 0.001716 & \\
\hline 3259 & Manufacture of other chemical products & -0.0029 & -0.0004 & 0.000161 & 0.000611 & 0.001699 & \\
\hline 4841 & General cargo haulage & -0.00284 & -0.00039 & 0.000158 & 0.000598 & 0.001663 & \\
\hline 3222 & Manufacture of paperboard and paper products & -0.00281 & -0.00039 & 0.000156 & 0.000593 & 0.001649 & \\
\hline 3256 & Manufacture of soap, cleaners and toilet preparations & -0.00281 & -0.00039 & 0.000156 & 0.000592 & 0.001648 & \\
\hline 3323 & Manufacture of metal structures and products of blacksmithing & -0.00281 & -0.00039 & 0.000156 & 0.000592 & 0.001647 & \\
\hline 3152 & Manufacture of wearing apparel & -0.0028 & -0.00039 & 0.000156 & 0.000591 & 0.001644 & \\
\hline 3313 & Basic aluminum industry & -0.00279 & -0.00038 & 0.000155 & 0.000587 & 0.001634 & \\
\hline 3345 & Manufacture of measuring, control, navigation and electronic medical equipment & -0.00278 & -0.00038 & 0.000154 & 0.000585 & 0.001629 & \\
\hline 3325 & Manufacture of fittings and locks & -0.00274 & -0.00038 & 0.000152 & 0.000577 & 0.001606 & \\
\hline 3241 & Manufacture of products of petroleum and coal & -0.00274 & -0.00038 & 0.000152 & 0.000577 & 0.001605 & \\
\hline 1153 & Services related to forest harvesting & -0.00273 & -0.00038 & 0.000152 & 0.000575 & 0.0016 & \\
\hline 3261 & Manufacture of plastic products & -0.00272 & -0.00037 & 0.000151 & 0.000573 & 0.001595 & \\
\hline 4851 & Urban and suburban public fixed-route passenger transport & -0.00264 & -0.00036 & 0.000147 & 0.000557 & 0.001548 & \\
\hline 3339 & Manufacture of other machinery and equipment for general industry & -0.00264 & -0.00036 & 0.000147 & 0.000556 & 0.001548 & \\
\hline 3399 & Other Manufacturing & -0.00263 & -0.00036 & 0.000146 & 0.000554 & 0.001541 & \\
\hline 3336 & Manufacture of internal combustion engines, turbines and transmissions & -0.00261 & -0.00036 & 0.000145 & 0.00055 & 0.001531 & \\
\hline 3363 & Manufacture of parts for motor vehicles & -0.00261 & -0.00036 & 0.000145 & 0.00055 & 0.001529 & \\
\hline 3312 & Manufacture of iron and steel products & -0.00255 & -0.00035 & 0.000142 & 0.000538 & 0.001496 & \\
\hline 3342 & Manufacture of communication equipment & -0.00243 & -0.00034 & 0.000135 & 0.000513 & 0.001427 & \\
\hline 3353 & Manufacture of electricity generation and distribution equipment & -0.00241 & -0.00033 & 0.000134 & 0.000508 & 0.001414 & \\
\hline 3361 & Manufacture of cars and trucks & -0.0022 & -0.0003 & 0.000122 & 0.000464 & 0.001291 & \\
\hline 3341 & Manufacture of computers and peripheral equipment & -0.0018 & -0.00025 & $1.00 \mathrm{E}-04$ & 0.000379 & 0.001055 & \\
\hline 3343 & Manufacture of audio and video equipment & -0.00179 & -0.00025 & 9.96E-05 & 0.000378 & 0.001051 & \\
\hline & 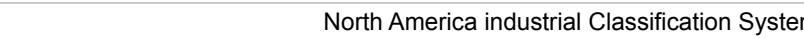 & Ho & f 2007. & & & & \\
\hline
\end{tabular}

Table 9: Branches of economic activity that least impact on the sensitivity of poverty in the rural and urban population for well-being lines by household income decile. 
Citation: Ledesma-Carrión DE, Hernández-Hernández L (2017) Is the Poverty of the Country a Consequence of the Structure of the Mexican Economy? Int J Account Res 5: 163. doi:10.4172/2472-114X.1000163

Page 14 of 14

of economic activity specialized in metallurgical and petroleum technologies.

Differences in the impact of poverty alleviation between rural and urban areas are notable as well as among low income deciles.

The most vulnerable population is income in decile I in rural areas and in decile II in urban areas.

\section{References}

1. Ortiz-Mena A (1998) El desarrollo estabilizador: Reflexiones sobre una época, Colección: Fideicomiso Historia de las Américas FCE, Colmex, FHA.

2. http://mexicomaxico.org/voto/crisismex.htm

3. Lasa A, Deuda (1989) inflación y déficit. Una nota sobre la corrección inflacionaria; Estrategia, desarrollo y política económica, UAM-1. Serie de investigación 1.

4. Pyatt G, Round J (1979) Accounting and Fixed Price Multipliers in a Social Accounting Matrix Framework. The Economic Journal 89: 850-873.

5. Defourny J, Thorbecke E (1984) Strutural Path Analysis and Multiplier Decomposition within a Social Accounting Matrix Framework. The Economic Journal 94: 111-136.

6. Nuñez G (2000) A Social Accounting Matrix of Mexico, Working papers in InputOutput Economics. International Input-Output Association WPIOX 08-001.

7. Minzer R, Solís V (2000) A Social Accounting Matrix of Mexico, Análisis estructural de la economía mexicana: Algunas medidas de reforma social y su impacto en la recaudación tributaria y la pobreza.

8. Thorbecke E, Jung HS (1996) A multiplier decomposition method to analyze poverty alleviation. Journal of Development Economics 48: 279-300.

9. Pineda-Solís AF (2003) Vinculación sectorial de la economía mexicana: el sector financiero y el sector real. Un análisis desde la perspectiva de la Matriz de Contabilidad Social de México. UNAM.
10. Sistema de Información Arancelaria Vía Internet, SIAVI.

11. Sistema de Cuentas Nacionales de México Instituto Nacional de Estadística y Geografía, INEGI.

12. United States Census Bureau, North America Industrial Classification System 2007.

13. Ledesma-Carrión DE, Hernández-Hernández L, Muciño-Porras MTL, DaudéBalmer RJ (2015) Social accounting matrix founded on system of national accounting: case of Mexico. Asian Journal of Science and Technology 6: 14871522.

14. Ledesma-Carrión DE, Hernández-Hernández L, Muciño-Porras MTL (2016) Social Accounting Matrix on the Base of the Mexican System of National Accounting, Economics World 4: 111-127.

15. CONEVAL, Metodología para la medición multidimensional de la pobreza en México, 2 edición.

16. Kim K. Hypothetical integration in a social accounting matrix and fixed price multiplier analysis, Working papers in Input-Output Economics. International Input-Output Association.

17. Pyatt G, Round J (1977) Social Accounting Matrices for Development Planning Review of Income and Wealth 23: 339-364.

18. Pyatt G, Round J (1985) Social accounting matrices, A World Bank Symposium USA, ISBN 0-8213-0550-6.

19. Salvatore D (2004) Growth and poverty in a globalizing world. Journal of Policy Modeling 26: 543-551.

20. Leyva-Parra G, El ajuste del ingreso de la ENIGH con la contabilidad naciona y la medición de la pobreza en México, Secretaría de Desarrollo Social, Serie: Documentos de Investigación 19

21. Thorbecke $E$ (2000) The use of social accounting matrices in modeling, P26th General Conference of The International Association for Research in Income and Wealth, Cracow, Poland, 27 August to 2 September. 